IZA DP No. 9761

Racial Differences in Labor Market Transitions and the Great Recession

Kenneth A. Couch

Robert Fairlie

Huanan Xu

February 2016 


\title{
Racial Differences in Labor Market Transitions and the Great Recession
}

\author{
Kenneth A. Couch \\ University of Connecticut \\ Robert Fairlie \\ University of California, Santa Cruz \\ and IZA
}

Huanan Xu

University of Connecticut

\section{Discussion Paper No. 9761 \\ February 2016}

\author{
IZA \\ P.O. Box 7240 \\ 53072 Bonn \\ Germany \\ Phone: +49-228-3894-0 \\ Fax: +49-228-3894-180 \\ E-mail: iza@iza.org
}

Any opinions expressed here are those of the author(s) and not those of IZA. Research published in this series may include views on policy, but the institute itself takes no institutional policy positions. The IZA research network is committed to the IZA Guiding Principles of Research Integrity.

The Institute for the Study of Labor (IZA) in Bonn is a local and virtual international research center and a place of communication between science, politics and business. IZA is an independent nonprofit organization supported by Deutsche Post Foundation. The center is associated with the University of Bonn and offers a stimulating research environment through its international network, workshops and conferences, data service, project support, research visits and doctoral program. IZA engages in (i) original and internationally competitive research in all fields of labor economics, (ii) development of policy concepts, and (iii) dissemination of research results and concepts to the interested public.

IZA Discussion Papers often represent preliminary work and are circulated to encourage discussion. Citation of such a paper should account for its provisional character. A revised version may be available directly from the author. 
IZA Discussion Paper No. 9761

February 2016

\section{ABSTRACT \\ Racial Differences in Labor Market Transitions and the Great Recession*}

Labor force transitions are empirically examined using CPS data matched across months from 1996-2012 for Hispanics, African-Americans and whites. Transition probabilities are contrasted prior to the Great Recession and afterwards. Estimates indicate that minorities are more likely to be fired as business cycle conditions worsen. Estimates also show that minorities are usually more likely to be hired when business cycle conditions are weak. During the Great Recession, the odds of losing a job increased for minorities although cyclical sensitivity of the transition declined. Odds of becoming re-employed declined dramatically for blacks, by 2-4 percent, while the probability was unchanged for Hispanics.

JEL Classification: J15, J64

Keywords: $\quad$ unemployment, race, minorities, labor market, labor force, dynamics, Great Recession

Corresponding author:

Robert W. Fairlie

Department of Economics

University of California, Santa Cruz

Santa Cruz, CA 95064

USA

E-mail: rfairlie@ucsc.edu

\footnotetext{
* We thank Delia Furtado and seminar participants at the University of Connecticut, and two anonymous referees for their comments and suggestions.
} 


\section{Introduction}

Differences in unemployment rates between African-Americans and whites have long been the focus of popular concern. There are indeed persistent differences in the measured rates of unemployment across racial groups in the United States. The ratio of black-to-white unemployment rates has been roughly 2-to-1 for several decades since the 1950s (Fairlie and Sundstrom 1997, 1998). In Richard Freeman’s (1973) classic study of racial patterns of labor market status from 1948 to 1972, he found that the level of employment for blacks was more volatile than that for whites and that the unemployment rate for blacks rises more than that for whites in percentage points when the economy weakens. Based on these findings, Freeman (1973) proposed a "last in, first out” pattern of black employment over the business cycle.

While much of the existing literature regarding the United States looks at increases and decreases in the unemployment rate to make inferences about rates of layoff and hiring over the business cycle (Allegretto and Lynch 2010; Bradbury 2000; Cattan 1988; Freeman 1973; Freeman and Rodgers 1999; Holzer and Offner 2006; Hoynes, Miller, and Schaller 2012), relatively few studies have examined the underlying transitions themselves (Couch and Fairlie 2010). ${ }^{1}$ Changes in unemployment are driven by rates of layoff and hiring so that inferences based on the presumption that one transition alone drives the change in the level of unemployment may be inaccurate.

Similar to the earlier work of Freeman (1973), Cattan (1988) and Defreitas (1986) each document the growing presence of Hispanics in the U.S. work force in the 1980s. They show that the Hispanic unemployment rate is typically about 1.5 times higher than the rest of the population, and they are concentrated as a group in job categories especially vulnerable to business cycle downturns. While there is a sizeable literature (Abowd and Killingsworth 1984; Borjas and Tienda 1985; Hoynes 1999; Orrenius and Zavodny 2009) on the labor force status of Hispanics and Hispanic-white differences in the United States, to date, there has been no analysis of underlying labor market transitions that determine the unemployment rates of Hispanics. A better understanding

\footnotetext{
${ }^{1}$ Constant and Zimmerman (2014) and De la Rica and and Rebello-Sanz (2015) provide related analyses in the European contexts of Germany and Spain respectively.
} 
of unemployment dynamics among this rapidly growing population group helps inform what the fundamental drivers are of changes in labor force aggregates. Hispanics now represent the largest minority group in the United States.

The National Bureau of Economic Research (NBER) dates the last recession as running from December 2007 to June 2009. At 18 months, it was the longest contraction period since the Great Depression. During this period the labor market also experienced its deepest downturn in the postwar era. The national unemployment rate rose 5 percentage points in only a year and a half, reaching a peak of 10 percent in October 2009. Because of these trends the recent recession was popularly dubbed the "Great Recession." Although much research has focused on unemployment and broader labor market conditions during the Great Recession, surprisingly previous research has not examined labor market transitions among blacks and Hispanics in the U.S. during this period and the subsequent period of slow employment growth. ${ }^{2}$

In this study, we use Current Population Survey (CPS) micro-data matched across adjacent months from 1996 to 2012 to examine two previously unanswered questions in the literature regarding unemployment dynamics. First, the paper examines differences between Hispanics and whites in addition to differences between blacks and whites in labor market transitions in relation to the assertion that one would expect minorities to be the last hired at the end of growth periods and the first fired during recessions (Freeman 1973). Specifically, the rate at which minorities become employed should be pro-cyclical such that it should rise relative to that for whites when the economy grows and become most pronounced at the end of the expansion. The probability of becoming unemployed for minorities would be expected to be countercyclical such that it should rise relative to that for whites as the economy worsens. Such a pattern of labor market transitions would be consistent with the pattern often referred to as minorities being the last hired and first fired. The extension to

\footnotetext{
2 The continued period of poor labor market conditions are reflected in average unemployment rates that through the end of the sample period examined here, 2012, the unemployment rate among the civilian workforce was 8.2 percent.
} 
consider Hispanics in the United States in this framework is new to this literature. ${ }^{3}$

Second, the paper is the first to examine racial differences in labor market transitions in the U.S. through the Great Recession. It makes use of monthly matched individual level CPS data from 1996 to 2012. This 17-year period is broken up into two sub-periods to provide a contrast between the experiences of different groups in the Great Recession versus prior years. This is the first detailed examination of changes in unemployment dynamics among Hispanics, blacks and whites in the United States brought on by the Great Recession.

The paper proceeds as follows. Section 1 briefly reviews the prior literature on the racial unemployment gap. Section 2 describes the data, sample selection and variable construction. Section 3 presents descriptive statistics and plots of the underlying transition rates between employment and unemployment. Sections 4 and 5 discuss the empirical model and results for transitions between unemployment and employment respectively. Section 6 extends the analysis to include transitions into and out of the labor force. Section 7 provides a test for changes across the pre-Great Recession period and afterwards. Section 8 contains a discussion of conclusions.

\section{Previous Literature}

Richard Freeman (1973) first discussed "the widely asserted last in, first out pattern of black employment over the cycle” in his study of racial patterns of labor market status. Using annual data from 1948 to 1972, he explored the hypothesis by estimating separate regressions for labor market outcomes that included a trend variable and deviation of real gross national product from its trend by race. He found that the employment of blacks is strongly cyclical, rising relative to other groups in expansions and falling in recessions, and is of greater sensitivity, compared to whites, to short-run changes in GNP.

Studies of the business cycle and the relative employment status of blacks include

\footnotetext{
3 The analysis by de la Rica and Rebello-Sanz (2015) considers similar patterns among Spanish men and women.
} 
Katherine Bradbury's (2000) research on the gaps between disadvantaged groups and the rest of the economy from 1970 to 2000. She offered several explanations for historical patterns and provided some predictions as to how differences across groups in labor force status should respond to recessions or to an expansion like that of the 1990s. Her findings indicate that while virtually all groups see improvements in labor market outcomes during periods of growth, racial unemployment gaps had not been reduced to zero even during the sustained expansion of the 1990s.

Holzer and Offner (2006) used data from the CPS’s Outgoing Rotation Groups (CPS-ORG) to estimate the trends and cyclical rates of unemployment among young black men relative to other groups during the period from 1979 to 2000. Their findings suggested that employment trends among blacks were more negative over time than those of less-educated white or Hispanic men. Many other studies of the movement of labor force aggregates in response to business cycle conditions have similarly examined the movement of aggregate measures relative to demand and agree that employment and unemployment of blacks are more sensitive to business cycle conditions than for whites (Bound and Freeman 1992; Clark and Summers 1981; Freeman and Rodgers 1999; Hoynes 1999).

Defreitas (1986) conducted a time-series study of the rapidly growing U.S. Hispanic labor force using quarterly CPS data from 1973 to 1985. The analysis reveals that the average unemployment rate of Hispanics is about 1.6 times that of whites and that the elasticity of the employment-to-population ratio with respect to aggregate demand is nearly twice that of the white population. Hoynes, Miller, and Schaller (2012) investigated movement of the employment rate, the unemployment rate, and the labor force participation rate by race-sex and education groups in the U.S. during the Great Recession and showed that the impacts of the Great Recession have been felt most strongly for black and Hispanic workers. They show that blacks and Hispanics experienced larger employment reductions and unemployment increases compared to whites. Their results show that the unemployment rate of blacks is more responsive to business cycle movements than the unemployment rate for Hispanics in the U.S., but 
the cyclicality for both groups is greater than for whites.

The above studies have primarily examined the movement of aggregate measures of the labor force (employment and unemployment) relative to demand to try to infer underlying labor market transitions associated with the timing of hiring and firing. The shortcoming of this approach is that sources of fluctuations over time that are caused by changes in transition rates into and out of the labor force status cannot be revealed by changes in the level of an aggregate. A better understanding of whether unemployment is increasing primarily due to increased firing (transition out of employment) or reduced hiring (transition into employment), or the extent to which it is attributable to both requires a direct examination of the related transitions.

The studies of Badgett (1994), Blanchard and Diamond (1990), and Abraham and Shimer (2001) developed a dynamic approach to explore differences in employment transitions and related these to movements of steady-state stocks of labor force aggregates over time. Badgett (1994) compared the effects of changing flows into and out of unemployment on the ratio of the black to the white unemployment rate. Using CPS data, the paper provides calculations of estimates of workers' net flows into and out of unemployment by comparing the stock of unemployed workers across months. Such dynamic analysis allows for more direct examination of the timing of hiring and firing patterns for racial groups over the business cycle. ${ }^{4}$

The papers of Blanchard and Diamond (1990) and Abraham and Shimer (2001) are important in developing theoretical frameworks that relate measures of the business cycle such as deviations of Gross Domestic Product from its potential level or local unemployment from a full employment level to both labor market transitions and steady state stocks of aggregate unemployment. Those papers provide a theoretical underpinning for studies such as this that are empirical in nature. One of the insights gained from those papers is that Markov transition probability matrices characterize the steady state stocks of labor force aggregates. In particular, inflows and outflows from

\footnotetext{
${ }^{4}$ A similar study is conducted by Constant and Zimmermann (2014) in Germany. In the paper they examined the labor market transitions among self-employment, employment, and unemployment, focusing on the immigrant-native differential across the business cycle.
} 
any state determine its level. ${ }^{5}$

Extending these prior studies, Couch and Fairlie (2010) provided a detailed examination of labor market transitions for prime-age black and white men to examine the last hired, first fired hypothesis using monthly matched CPS data from 1989 to 2004. The study is important in modeling the relationship of underlying transitions that are elements of Markov transition probability matrices to aggregate rates of unemployment and explaining the cyclical movement of blacks relative to whites between employment, unemployment, and nonparticipation over the business cycle. Blacks are found to be the first fired as the business cycle weakens; however, no evidence was found that blacks are the last hired. The study might be summarized as supporting a pattern of blacks being first fired but also first hired in the period examined.

Two important questions, however, are not examined in the previous literature. First, what are the dynamic unemployment patterns of Hispanics in the U.S. relative to whites? Is the pattern of first fired, first hired over the business cycle found for blacks in the U.S. similar for Hispanics? Second, was the Great Recession associated in the U.S. with altered patterns of labor dynamics relative to earlier periods for Hispanics, blacks and whites, or were prior patterns even more pronounced in this severe economic downturn? Both questions are examined in this paper.

\section{Data}

\subsection{Sample Selection}

This paper uses individual-level records from matched monthly CPS data observations from 1996 to 2012 encompassing a 203-month time span. The CPS itself is a monthly survey of a probability sample of around 50,000 dwelling units a month. Instead of surveying a completely new set of housing units each month, the CPS re-samples households. The sample is divided into eight representative subsamples called rotation groups, and each month a new rotation group is added to the overall sample. Housing

\footnotetext{
${ }^{5}$ For example, in a two state model the level of either category is determined by the entry rate divided by the entry plus the exit rate.
} 
units in each rotation group are interviewed for four consecutive months, followed by an 8-month break, and then interviewed for four more months before exiting the survey. This rotation pattern of the CPS makes it possible to match information on individuals across adjacent months by linking surveys.

The matching algorithm for the data is the same as the one used in Fairlie (2013), which is related to earlier work by Madrian and Lefgren (2000). Individuals present in the data in adjacent months have their data matched so that their labor market transitions can be directly observed. As the CPS data are the basis for calculation of the official U.S. unemployment rates, this matching procedure allows the labor market transitions of survey respondents to be related to aggregate unemployment at a monthly frequency.

After matching, the sample selected for this analysis consists of black, Hispanic and white males ages 25-55 to avoid modeling issues that would otherwise arise because of transitions associated with school enrollment, retirement, and childbearing. The white and black racial groups here are defined as white only and black only. The sample excludes any combined races such as White-Asian or Black-Asian. Hispanic in the sample is coded as an ethnicity and may be of any race. Thus, non-Hispanic whites, non-Hispanic blacks, and Hispanics are constructed as three mutually exclusive groups in the analysis. In the following part of this paper, minorities refer to the black and Hispanic groups as compared to the majority group that is represented by white males. As can be seen in Table 1, even when limiting the sample to prime-aged males, the sample sizes are still quite large. Roughly 3.3 million observations are available for the analysis. It would be interesting in future research to further disaggregate these categories into smaller groupings such as different countries of origin for the Hispanic portion of the sample.

\subsection{Indicator for Labor Market Transition}

To examine underlying transition probabilities, this paper first focuses on transitions between employment and unemployment ${ }^{6}$ by limiting the analysis sample to

\footnotetext{
${ }^{6}$ The paper does not specify the influence of involuntary job leavers separately from voluntary job
} 
individuals who are in the labor force for any two consecutive months and excluding those who are not in the labor force. To better relate the underlying transitions to the aggregate stock of unemployment, the sample is expanded to include those not in the labor force in the second part of the analysis (Section 6). The linking of data across months makes it possible to create indicators for labor market transitions from one month to the next. The unemployment entry rate represents the probability that a person employed in one month will be unemployed in the following month. The unemployment exit rate represents the probability that a person unemployed in one month will be employed in the following month.

\subsection{Business Cycle Measure}

To measure business cycle conditions, a monthly state-level variable is constructed to capture demand in the labor market. The state-level business cycle control variable measures the deviation of the aggregate state unemployment rate from the national natural rate of unemployment (NRU). It captures shocks in state demand relative to a national measure of full employment. Variation in transitions in labor force status are driven in response to these different business cycle conditions across states. Data for the monthly aggregate state unemployment rate is retrieved from Bureau of Labor Statistics (BLS). The NRU applied in the analysis is 5.28 and was drawn from separate estimates of an expectations-augmented Phillips curve. ${ }^{7}$ A practical reason for using deviations of state level unemployment from a national NRU as the measure of local business cycle activity is that other measures that might be used are not available at a monthly frequency.

\footnotetext{
leavers because voluntary job leavers (i.e. those who quit to become unemployed) account for a very small percentage of job leavers within each racial group defined in the sample (they account for less than 5 percent in a recent recession year in the sample and less than 10 percent in a recent post-recession year. Although we could not check this with the current data extract, given the small percentage of involuntary job leavers it is very unlikely that our findings would change if we removed them from the sample.

${ }^{7}$ The NRU of 5.28 is taken from the prior research of Couch and Fairlie (2010). More detail on its estimation can be found there (p. 232). Also, that prior work considered time varying NRU as a possibility and found that estimations similar to those carried out in this analysis were robust to that alternative procedure.
} 


\section{Transition Rates in the Sample Period and Trends over Time}

Table 1 reports estimates of the unemployment rate as well as transition probabilities between employment and unemployment of blacks, Hispanics, and whites for the whole sample period. These figures were constructed by taking the individual matched CPS data observations and tabulating weighted transition probabilities to enter into the probability matrix in the table. Over the period from 1996-2012, the unemployment rate was 4.26 percentage points higher for blacks than for whites, and 1.97 percentage points higher for Hispanics than for whites. For both blacks and Hispanics, more than $2 \%$ of employed men were unemployed by the following month, whereas only $1.07 \%$ of employed white men were unemployed by the following month. The monthly probability of becoming re-employed was quite different for blacks and Hispanics when compared to whites. The unemployment exit rate for black men was $24.43 \%$ showing that unemployed blacks were less likely to become reemployed by the following month than unemployed whites who had an unemployment exit rate of $29.58 \%$. However, with a higher unemployment exit rate of 37.02\%, unemployed Hispanics in the sample were more likely to become reemployed in the following month than unemployed whites. Overall, Hispanics have more churning into and out of unemployment.

To compare patterns before and after the Great Recession, Table 2 provides similarly constructed estimates except that the unemployment rates and transition probabilities for different racial groups are reported for a period prior to the beginning of the Great Recession and afterwards. The racial unemployment gaps of blacks and Hispanics relative to whites stood at 6.28 and 2.51 percentage points respectively after the Great Recession. The unemployment gaps of blacks and Hispanics almost doubled relative to where they stood compared to whites (3.33 and 1.32 percentage points respectively) before the Great Recession. The magnitude of racial differences in transition rates into unemployment is also smaller in the period of 1996-2007 and larger in the period of 2008-2012 when compared to estimates in Table 1. 
Table 1. Unemployment and Transition Rates by Race: Matched Current Population Surveys, 1996-2012

\begin{tabular}{lcccccccc}
\hline & & & & & & & \multicolumn{2}{c}{ White-Black } \\
Difference(\%) & $\begin{array}{c}\text { White-Hispanic } \\
\text { Difference(\%) }\end{array}$ \\
\hline Unemployment Rate & 3.62 & $2,647,856$ & 7.88 & 259,816 & 5.59 & 379,156 & -4.26 & -1.97 \\
Unemployment Entry Rate & 1.07 & $2,555,860$ & 2.08 & 239,806 & 2.09 & 358,332 & -1.01 & -1.02 \\
Unemployment Exit Rate & 29.58 & 91,996 & 24.43 & 20,010 & 37.02 & 20,824 & 5.15 & -7.44 \\
\hline
\end{tabular}

Notes: The sample consists of males aged 25-55 who are in the labor force for any two consecutive months. All estimates are calculated using sample weights provided by the CPS. 
Table 2. Unemployment and Transition Rates by Race: Matched Current Population Surveys

\begin{tabular}{|c|c|c|c|c|c|c|c|c|}
\hline & White(\%) & $\mathrm{N}$ & Black(\%) & $\mathrm{N}$ & Hispanic(\%) & $\mathrm{N}$ & $\begin{array}{l}\text { White-Black } \\
\text { Difference(\%) }\end{array}$ & $\begin{array}{l}\text { White-Hispanic } \\
\text { Difference(\%) }\end{array}$ \\
\hline \multicolumn{9}{|l|}{ 1996-2007 } \\
\hline Unemployment Rate & 2.79 & $1,928,630$ & 6.12 & 183,697 & 4.11 & 253,275 & -3.33 & -1.32 \\
\hline Unemployment Entry Rate & 0.96 & $1,875,443$ & 1.91 & 172,495 & 1.76 & 242,832 & -0.95 & -0.8 \\
\hline Unemployment Exit Rate & 35.22 & 53,187 & 30.4 & 11,202 & 43.7 & 10,443 & 4.82 & -8.48 \\
\hline \multicolumn{9}{|l|}{ 2008-2012 } \\
\hline Unemployment Rate & 5.74 & 719,226 & 12.02 & 76,119 & 8.25 & 125,881 & -6.28 & -2.51 \\
\hline Unemployment Entry Rate & 1.36 & 680,417 & 2.51 & 67,311 & 2.71 & 115,500 & -1.15 & -1.35 \\
\hline Unemployment Exit Rate & 22.55 & 38,809 & 17.26 & 8,808 & 31.04 & 10,381 & 5.29 & -8.49 \\
\hline
\end{tabular}

Notes: The sample consists of males aged 25-55 who are in the labor force for any two consecutive months. All estimates are calculated using sample weights provided by the CPS. 
Another strong pattern in Table 2 is large within groups changes in transition rates in the period after the Great Recession relative to before it began. For example, among whites, blacks, and Hispanics, rates of entry into unemployment increased from .96 to 1.36, 1.91 to 2.51 , and 1.76 to 2.71 percent respectively. Movements in the transition rates from unemployment to employment changed more dramatically. Among whites, blacks and Hispanics, rates of re-employment fell from 35.2 to 22.6, 30.4 to 17.26 and 43.7 to 31.0 percent respectively. These dramatic reductions in rates of re-employment across all groups are a key factor in explaining increased unemployment during the Great Recession.

The seasonally adjusted aggregate unemployment rate and the underlying transitions are plotted in Figures 1-3 to show their variation over the business cycle. Figure 1 shows the unemployment rates of blacks, Hispanics, and whites from 1996 to 2012. The gaps between minorities and whites were the smallest in the sample period of the late 1990s near the conclusion of a prolonged period of economic expansion. After 2000 the gaps widen and then remain roughly constant until the economy entered the recession in 2008. ${ }^{8}$ The racial unemployment gaps were greatest in the period following the initiation of the Great Recession.

Figure 2 shows the movement of unemployment entry rates by race from 1996 to 2012. The transition rates from employment to unemployment are typically doubled for blacks and Hispanics relative to whites during the sample period. The racial gaps between minorities and whites appear to be most narrow in the years 1999 and 2000 when the business cycle peaked. The gaps have become visibly more pronounced since the Great Recession began.

Figure 3 shows the movement of unemployment exit rates by race from 1996 to 2012. There is not a large gap in the black and white series while the Hispanic exit rate from unemployment exceeds that of whites for most of the sample period. All series appear to be strongly associated with the business cycle such that peaks appear around

\footnotetext{
${ }^{8}$ The Great Recession officially began in December of 2007. Thus, 2008 was the first full recessionary year.
} 
the growth period of late 1990s and troughs appear after the 2008 Great Recession.

In examining these series, the relatively large rate at which blacks and Hispanics enter unemployment relative to the fairly similar rates at which all groups exit unemployment shows that the transition from employment to unemployment is more important in explaining their relatively high unemployment rates. Blacks as a group have the lowest exit rates from unemployment to employment which also contributes to their relatively high unemployment rate. Hispanics have the most rapid exit rates from unemployment which is why their group rate of unemployment (Figure 1) is always below that of Blacks.

\section{Model}

To examine racial differences in the transition probabilities with respect to business cycle conditions, a linear probability model (LPM) estimated by ordinary least squares (OLS) that controls for individual and job characteristics is used in all of the multivariate estimations. The regression framework in the empirical model is as follows:

$$
\begin{aligned}
& T_{\text {pqist }}=\beta_{0}+\beta_{1} \text { Black }_{\text {ist }}+\beta_{2} \text { Hispanic }_{\text {ist }}+\beta_{3} \text { Undiff }_{\text {st }}+\beta_{4} \text { Undiff }_{\text {st }} \times \text { Black }_{\text {ist }} \\
& +\beta_{5} \text { Undiff }_{\text {st }} \times \text { Hispanic }_{\text {ist }}+\beta_{6} \text { Undiff }_{\text {st }} \times{\text { Rising }(\text { Falling })_{t}}+\beta_{7} \text { Undiff }_{\text {st }}
\end{aligned}
$$

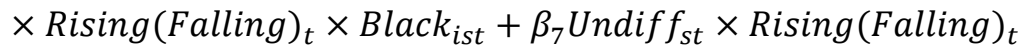

$$
\begin{aligned}
& \times \text { Hispanic }_{i s t}+\chi_{i s t} \boldsymbol{\delta}+\alpha_{s}+\gamma_{t}+\epsilon_{i s t}
\end{aligned}
$$

where $i$ references the individual, $s$ their state, and $t$ the month. The dependent variable $T$ (transition probability) is a binary variable representing the probability that a person in state $p(\mathrm{U}, \mathrm{E}$, or NLF) in one month will be in state $q(\mathrm{U}, \mathrm{E}$, or NLF) in the following month, where $\mathrm{U}$ is unemployment, $\mathrm{E}$ is employment, and NLF is not in the labor force. Black is a dummy variable indicating whether an individual is black. Hispanic is a dummy variable indicating whether an individual is Hispanic. Undiff is the business cycle control variable measuring the deviation of the state demand relative to a national measure of full employment, which is equal to the state-level aggregate unemployment rate minus the national natural rate of unemployment (NRU). 
Figure 1. Seasonally Adjusted Monthly Unemployment Rates by Race for Men Aged 25-55: Current Population Surveys, 1996-2012

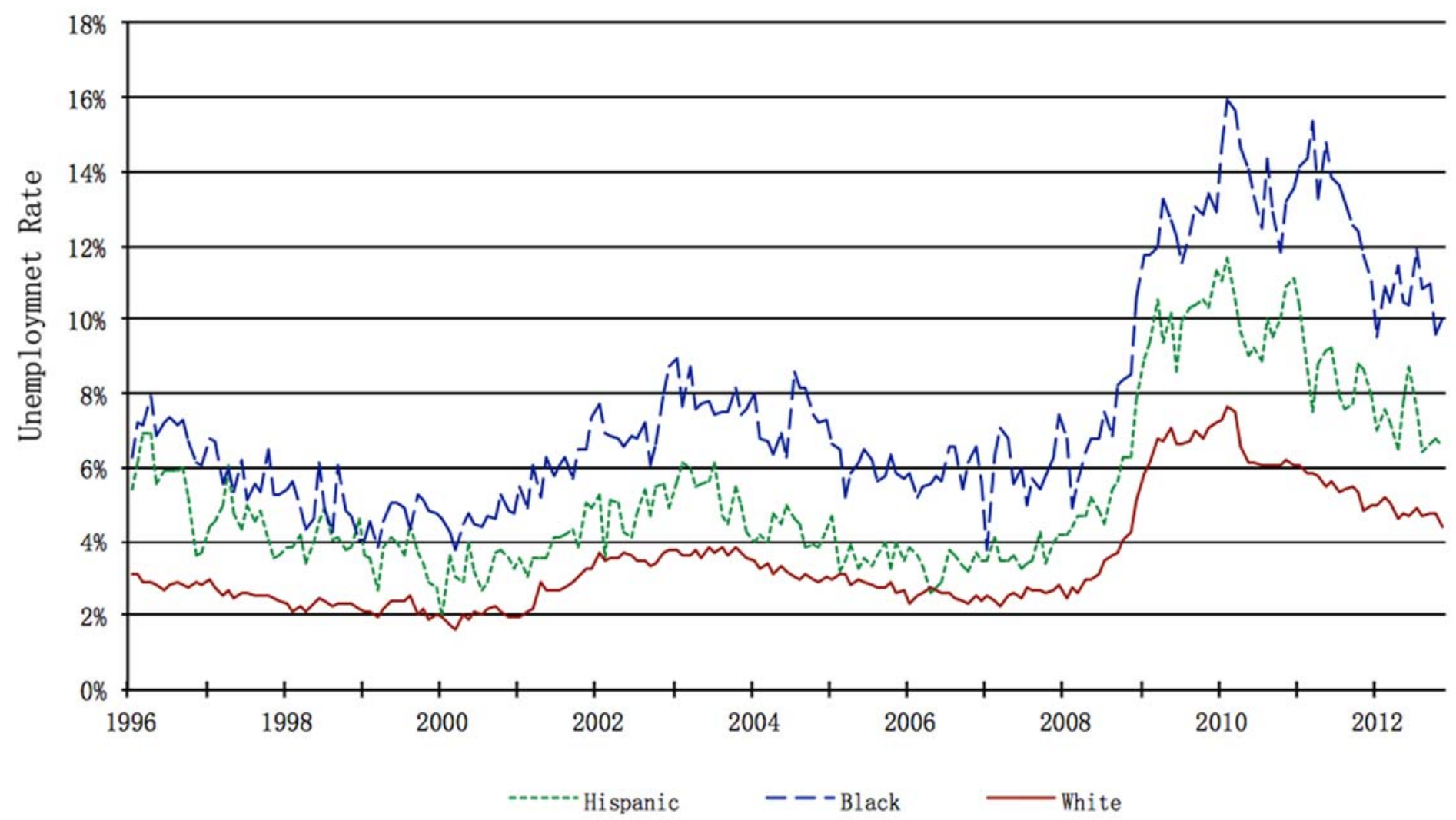


Figure 2. Seasonally Adjusted Monthly Unemployment Entry Rates by Race for Men Aged 25-55: Current Population Surveys, 1996-2012

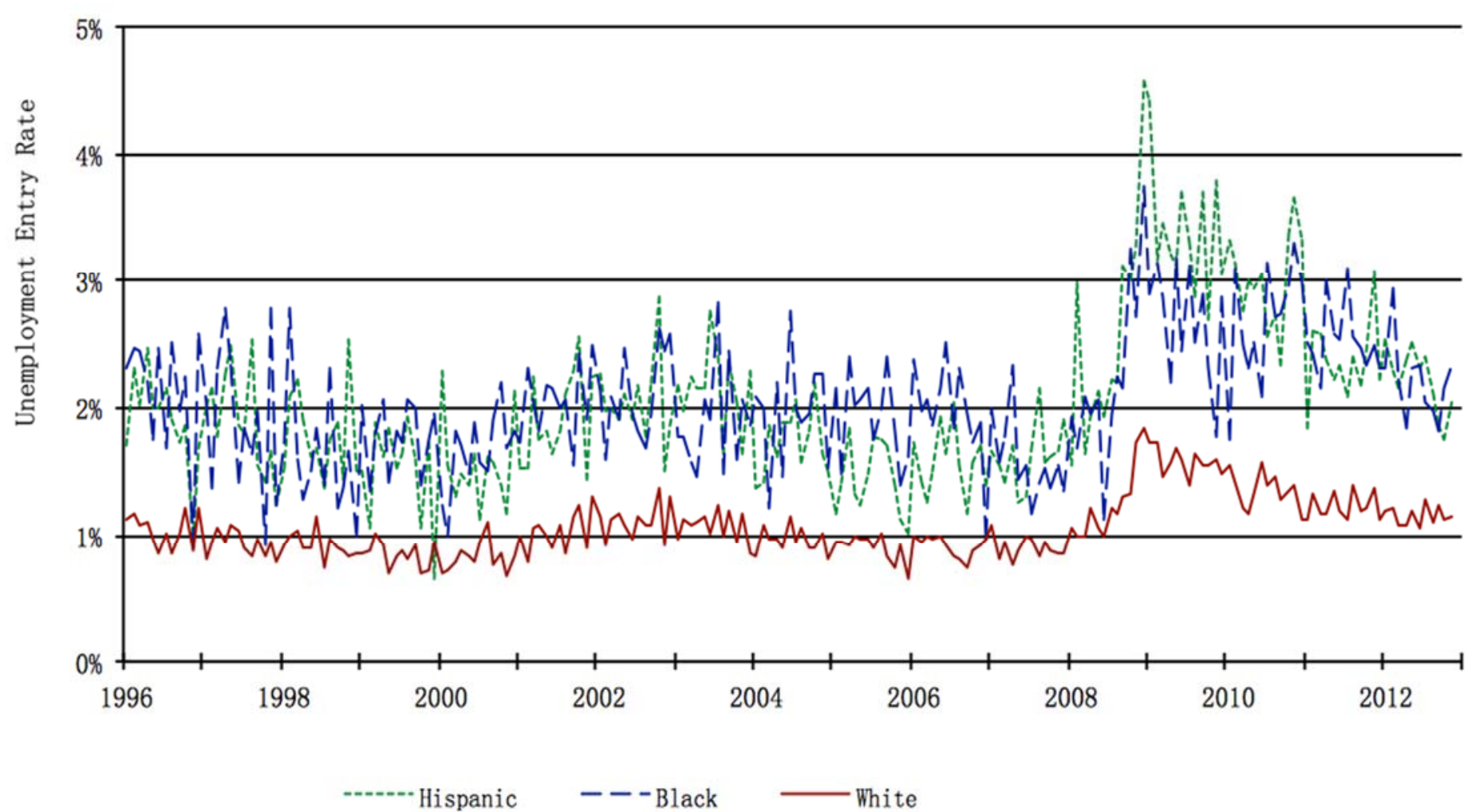


Figure 3. Seasonally Adjusted Monthly Unemployment Exit Rates by Race for Men Aged 25-55: Current Population Surveys, 1996-2012

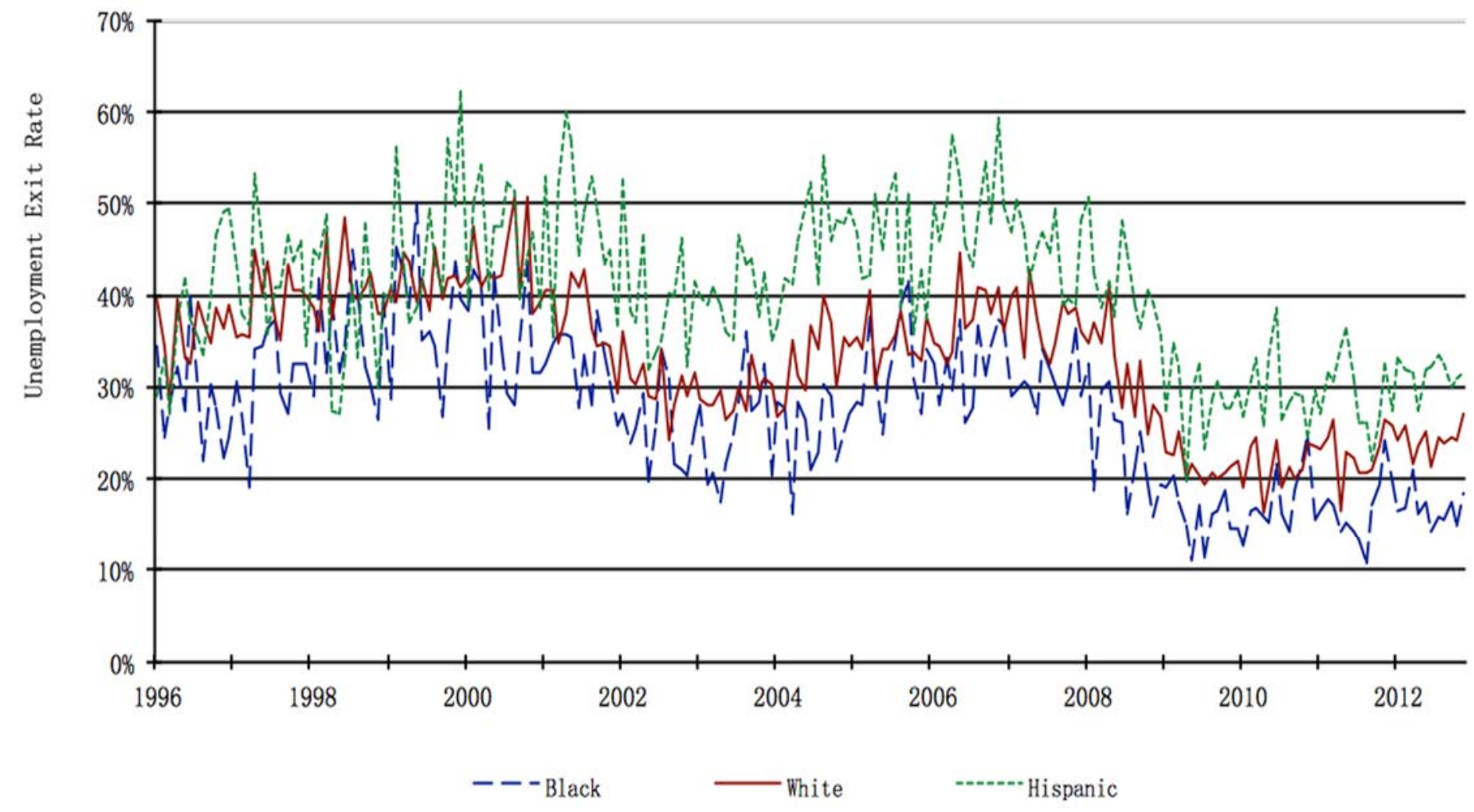


Rising (Falling) is a dummy variable for whether it is a period of rising (falling) aggregate unemployment ${ }^{9} . \boldsymbol{X}$ is a set of control variables including age, age-squared, marital status, education, and two-digit occupation and industry codes. $\alpha$ and $\gamma$ represent state and month fixed effects, respectively. $\varepsilon$ is the error term. The main coefficients of interest are $\beta_{4}$ and $\beta_{5}$, which measure the sensitivity of blacks and Hispanics to business cycle conditions. Standard errors are calculated using methods that account for clustering due to multiple observations per individual.

\section{Empirical Results for the Unemployment Transitions}

\subsection{Transition Probability from Employment to Unemployment}

Panel A of Table 3 shows OLS estimates for the transition probability from employment to unemployment for the period from 1996-2012. Specification 1 reports estimates for the dummy variable for black and Hispanic and the business cycle control from a model that also includes measures of age and its square, marital status, education, occupation, industry, and state and month fixed effects. The black-white differential in the transition probability is 0.97 percentage points. The Hispanic-white differential is 0.34 percentage points. The parameter for the business cycle control indicates that the probability of moving from employment to unemployment increases as demand weakens for all workers. Appendix Tables A.1, A.2, and A.3 contain descriptive statistics for the variables used in the regressions when transitions among those in the labor force are considered (between the states of unemployment and employment).

Specification 2 includes the interactions between the dummy variables for black and Hispanic, and the business cycle control variable along with the same regressors contained in Specification 1. Blacks and Hispanics have a somewhat higher base probability of entering unemployment than whites, 0.009 and 0.002 respectively. The estimate for the business cycle control variable indicates that as the unemployment rate

\footnotetext{
${ }^{9}$ Rising (falling) takes the value 1 for a month when the state-level unemployment rate in the following month is higher (lower) than the unemployment rate in the current month, and takes the value 0 for a month when the state-level unemployment rate in the following month is lower (higher) or the same as that in the current month.
} 
increases by 1 percentage point, all men have a 0.12 percentage point higher probability of entering unemployment. The interaction terms indicate that both black and Hispanic men have a stronger cyclical response than whites. The interaction term between being black and the business cycle variable indicates that for each percentage-point increase in unemployment, the transition probability for blacks rises by 0.07 of a percentage point more than for whites. And the interaction term between being Hispanic and the business cycle shows that for each percentage-point increase in unemployment, the transition probability for Hispanics rises by 0.12 of a percentage point more than for whites. Both of these results are statistically significant at conventional levels across all specifications of the model.

Specification 3 drops the extra control variables included in Specification 2 to examine their influence on the parameter estimates. Comparing these two columns, one can see that the parameter estimates associated with the interactions between the indicators for minority status and the business cycle barely change. Thus, the inclusion or exclusion of the control variables has little influence on the relationship between the movement of blacks and Hispanics into unemployment and the business cycle.

Specification 4 includes an interaction between the business cycle control variable, a dummy variable for whether it is a period of rising aggregate unemployment, and the dummy variables for minority status to test whether the unemployment entry rate among minorities responds more strongly when the labor market is becoming more slack. The interaction term for blacks is statistically insignificant and does not provide any evidence that blacks respond differently to business cycle conditions in periods of rising unemployment, whereas the relevant parameter for Hispanics is positive and statistically significant showing that unemployment transitions for Hispanics increase more sharply in periods of rising unemployment relative to other months. Overall, the results from Panel A are consistent with the view that minorities are first fired during a recession.

Panel A of Tables 4 and 5 report additional OLS estimates of a linear probability model for the unemployment entry rate for the sample periods of 1996-2007 and 2008- 
2012, respectively (before the Great Recession and afterwards). Panel A of Table 4 shows that both blacks and Hispanics have higher monthly transition probabilities from employment to unemployment than whites. The transition probability also increases more for them than for whites for each percentage-point increase in unemployment based on the estimates for the interaction between minority status and the business cycle. However, their rates of transition into unemployment also do not respond more strongly to business cycle conditions in periods of rising unemployment. These estimates before the Great Recession provide evidence that is consistent with the evidence reported for blacks in the earlier period from 1989 to 2004 by Couch and Fairlie (2010). ${ }^{10}$ This estimates from Panel A of Table 4 are also largely consistent with parameter estimates found in Panel A of Table 3 for the entire sample period.

Panel A of Table 5 reports the estimation results for the period from 2008-2012, the portion of the overall sample occurring after the initiation of the Great Recession. The results for Hispanics show that they are more likely to enter unemployment than whites, that their unemployment entry rate is more sensitive to business cycle conditions, and that there is an even stronger cyclical response when the labor market is becoming weaker (as Undiff increases). The results for blacks reveal a higher unemployment entry rate than whites but no group cyclical response beyond that for whites. In terms of cyclical response, the first fired hypothesis in the Great Recession is only supported by findings in the Hispanic-white comparison after the Great Recession. Thus, the finding that all minorities are the first fired over the entire sample period and prior to the Great Recession is not found for blacks in the post-recessionary period although all of the parameter estimates remain positive.

\footnotetext{
${ }^{10}$ Unemployment patterns for Hispanics were not examined in this study.
} 
Table 3. Labor Force Transitions Using Matched Current Population Surveys: 1996-2012

\begin{tabular}{lcccc}
\hline \multirow{2}{*}{ Regressor } & \multicolumn{4}{c}{ Specification } \\
\cline { 2 - 5 } Panel A. Linear Regressions for Probability & $(2)$ & $(3)$ & $(4)$ \\
\hline Black & $0.00973^{* * *}$ & $0.00931^{* * *}$ & $0.0104^{* * *}$ & $0.00931^{* * *}$ \\
& $(0.000355)$ & $(0.000351)$ & $(0.000350)$ & $(0.000351)$ \\
Hispanic & $0.00335^{* * *}$ & $0.00213^{* * *}$ & $0.00902^{* * *}$ & $0.00211^{* * *}$ \\
& $(0.000310)$ & $(0.000312)$ & $(0.000297)$ & $(0.000312)$ \\
Undiff & $0.00150^{* * *}$ & $0.00122^{* * *}$ & $0.00119^{* * *}$ & $0.00109^{* * *}$ \\
& $(0.0000469)$ & $(0.0000472)$ & $(0.0000473)$ & $(0.0000554)$ \\
Undiff*Black & & $0.000692^{* * *}$ & $0.000627^{* * *}$ & $0.000560^{* *}$ \\
& & $(0.000184)$ & $(0.000185)$ & $(0.000218)$ \\
Undiff*Hispanic & & $0.00118^{* * *}$ & $0.00119^{* * *}$ & $0.000925^{* * *}$ \\
& & $(0.000143)$ & $(0.000144)$ & $(0.000166)$ \\
Undiff*Rising & & & & $0.000388^{* * *}$ \\
& & & & $(0.0000877)$ \\
Undiff*Rising*Black & & & & 0.000385 \\
Undiff*Rising*Hispanic & & & & $(0.000373)$ \\
& & & & $\left(0.000285^{* * *}\right.$ \\
Sample size & $3,150,683$ & 3,683 & $3,150,683$ & $3,150,683$ \\
Mean of dependent variable & 0.01319 & 0.01319 & 0.01319 & 0.01319 \\
\hline
\end{tabular}

Panel B. Linear Regressions for Probability of Unemployment-to-Employment Transition

\begin{tabular}{lcccc}
\hline Black & $-0.0511^{* * *}$ & $-0.0549^{* * *}$ & $-0.0576^{* * *}$ & $-0.0550^{* * *}$ \\
& $(0.00429)$ & $(0.00537)$ & $(0.00535)$ & $(0.00537)$ \\
Hispanic & $0.0674^{* * *}$ & $0.0605^{* * *}$ & $0.0815^{* * *}$ & $0.0605^{* * *}$ \\
& $(0.00498)$ & $(0.00621)$ & $(0.00605)$ & $(0.00621)$ \\
Undiff & $-0.0324^{* * *}$ & $-0.0335^{* * *}$ & $-0.0335^{* * *}$ & $-0.0334^{* * *}$ \\
& $(0.000669)$ & $(0.000783)$ & $(0.000785)$ & $(0.000878)$ \\
Undiff*Black & & 0.00232 & 0.00160 & 0.00131 \\
& & $(0.00161)$ & $(0.00162)$ & $(0.00184)$ \\
Undiff*Hispanic & $0.00335^{* *}$ & $0.00330^{* *}$ & 0.00262 \\
& & $(0.00166)$ & $(0.00168)$ & $(0.00188)$ \\
Undiff*Falling & & & & -0.000451 \\
& & & & $(0.00116)$ \\
Undiff*Falling*Black & & & & 0.00290 \\
& & & & $0.00242)$ \\
Undiff*Falling*Hispanic & & & & $(0.00234)$ \\
& & 131,761 & 131,761 & 131,761 \\
Sample size & 131,761 & 0.30102 & 0.30102 & 0.30102 \\
Mean of dependent variable & 0.30102 & & & \\
\hline
\end{tabular}

Notes: The sample consists of males aged 25-55 who are in the labor force for any two consecutive months. All estimates are calculated using sample weights provided by the CPS. Standard errors are adjusted for multiple observations per individual. All specifications also included a constant, age, age squared, marital status, education, occupation and industry, and state and month fixed effects except Specification 3, which excludes age, marital status, education, occupation and industry.

${ }^{*} \mathrm{p}<0.1 ; * * \mathrm{p}<0.05 ; * * * \mathrm{p}<0.01$ 
Table 4. Labor Force Transitions Using Matched Current Population Surveys: 1996-2007

\begin{tabular}{|c|c|c|c|c|}
\hline \multirow{2}{*}{ Regressor } & \multicolumn{3}{|c|}{ Specification } & \multirow[b]{2}{*}{ (4) } \\
\hline & $(1)$ & $(2)$ & (3) & \\
\hline \multicolumn{5}{|c|}{ Panel A. Linear Regressions for Probability of Employment-to-Unemployment Transition } \\
\hline \multirow[t]{2}{*}{ Black } & $0.00900^{* * *}$ & $0.00943^{* * *}$ & $0.0107^{* * *}$ & $0.00944^{* * *}$ \\
\hline & $(0.000398)$ & $(0.000434)$ & $(0.000434)$ & $(0.000435)$ \\
\hline \multirow[t]{2}{*}{ Hispanic } & $0.00201^{* * *}$ & $0.00218^{* * *}$ & $0.00839^{* * *}$ & $0.00218^{* * *}$ \\
\hline & $(0.000343)$ & $(0.000350)$ & $(0.000336)$ & $(0.000350)$ \\
\hline \multirow[t]{2}{*}{ Undiff } & $0.00176^{* * *}$ & $0.00148^{* * *}$ & $0.00142^{* * *}$ & $0.00149^{* * *}$ \\
\hline & $(0.000104)$ & $(0.000104)$ & $(0.000104)$ & $(0.000114)$ \\
\hline \multirow[t]{2}{*}{ Undiff*Black } & & $0.00123^{* * *}$ & $0.00119^{* * *}$ & $0.00117^{* * *}$ \\
\hline & & $(0.000367)$ & $(0.000368)$ & $(0.000424)$ \\
\hline \multirow[t]{2}{*}{ Undiff*Hispanic } & & $0.00127^{* * *}$ & $0.00149^{* * *}$ & $0.00138^{* * *}$ \\
\hline & & $(0.000315)$ & $(0.000317)$ & $(0.000376)$ \\
\hline \multirow[t]{2}{*}{ Undiff*Rising } & & & & -0.0000343 \\
\hline & & & & $(0.000143)$ \\
\hline \multirow[t]{2}{*}{ Undiff*Rising*Black } & & & & 0.000188 \\
\hline & & & & $(0.000680)$ \\
\hline \multirow[t]{2}{*}{ Undiff*Rising*Hispanic } & & & & -0.000339 \\
\hline & & & & $(0.000628)$ \\
\hline Sample size & $2,287,455$ & $2,287,455$ & $2,287,455$ & $2,287,455$ \\
\hline Mean of dependent variable & 0.01160 & 0.01160 & 0.01160 & 0.01160 \\
\hline \multicolumn{5}{|c|}{ Panel B. Linear Regressions for Probability of Unemployment-to-Employment Transition } \\
\hline \multirow[t]{2}{*}{ Black } & $-0.0504^{* * *}$ & $-0.0504^{* * *}$ & $-0.0531^{* * *}$ & $-0.0505^{* * *}$ \\
\hline & $(0.00617)$ & $(0.00616)$ & $(0.00607)$ & $(0.00615)$ \\
\hline \multirow[t]{2}{*}{ Hispanic } & $0.0625^{* * *}$ & $0.0615^{* * *}$ & $0.0845^{* * *}$ & $0.0616^{* * *}$ \\
\hline & $(0.00725)$ & $(0.00727)$ & $(0.00695)$ & $(0.00727)$ \\
\hline \multirow[t]{2}{*}{ Undiff } & $-0.0482^{* * *}$ & $-0.0499^{* * *}$ & $-0.0512^{* * *}$ & $-0.0486^{* * *}$ \\
\hline & $(0.00257)$ & $(0.00290)$ & $(0.00294)$ & $(0.00333)$ \\
\hline \multirow[t]{2}{*}{ Undiff*Black } & & 0.000462 & -0.000540 & -0.00218 \\
\hline & & $(0.00561)$ & $(0.00567)$ & $(0.00697)$ \\
\hline \multirow[t]{2}{*}{ Undiff*Hispanic } & & 0.00944 & $0.0115^{*}$ & $0.0131^{*}$ \\
\hline & & $(0.00616)$ & $(0.00626)$ & $(0.00749)$ \\
\hline \multirow[t]{2}{*}{ Undiff*Falling } & & & & -0.00338 \\
\hline & & & & $(0.00446)$ \\
\hline \multirow[t]{2}{*}{ Undiff*Falling*Black } & & & & 0.00687 \\
\hline & & & & $(0.0102)$ \\
\hline \multirow[t]{2}{*}{ Undiff*Falling*Hispanic } & & & & -0.00944 \\
\hline & & & & $(0.0114)$ \\
\hline Sample size & 74,251 & 74,251 & 74,251 & 74,251 \\
\hline Mean of dependent variable & 0.35787 & 0.35787 & 0.35787 & 0.35787 \\
\hline
\end{tabular}

Notes: The sample consists of males aged 25-55 who are in the labor force for any two consecutive months. All estimates are calculated using sample weights provided by the CPS. Standard errors are adjusted for multiple observations per individual. All specifications also included a constant, age, age squared, marital status, education, occupation and industry, and state and month fixed effects except Specification 3, which excludes age, marital status, education, occupation and industry.

${ }^{*} \mathrm{p}<0.1 ; * * \mathrm{p}<0.05 ; * * * \mathrm{p}<0.01$ 
Table 5. Labor Force Transitions Using Matched Current Population Surveys: 2008-2012

\begin{tabular}{|c|c|c|c|c|}
\hline \multirow{2}{*}{ Regressor } & \multicolumn{3}{|c|}{ Specification } & \multirow[b]{2}{*}{$(4)$} \\
\hline & (1) & $(2)$ & (3) & \\
\hline \multicolumn{5}{|c|}{ Panel A. Linear Regressions for Probability of Employment-to-Unemployment Transition } \\
\hline \multirow[t]{2}{*}{ Black } & $0.0116^{* * *}$ & $0.0106^{* * *}$ & $0.0111^{* * *}$ & $0.0105^{* * *}$ \\
\hline & $(0.000742)$ & $(0.00116)$ & $(0.00117)$ & $(0.00116)$ \\
\hline \multirow[t]{2}{*}{ Hispanic } & $0.00527^{* * *}$ & $0.00271^{* * *}$ & $0.0122^{* * *}$ & $0.00242^{* *}$ \\
\hline & $(0.000625)$ & $(0.000960)$ & $(0.000935)$ & $(0.000960)$ \\
\hline \multirow[t]{2}{*}{ Undiff } & $0.00103^{* * *}$ & $0.000844^{* * *}$ & $0.000776^{* * *}$ & $0.000704^{* * *}$ \\
\hline & $(0.000106)$ & $(0.000106)$ & $(0.000107)$ & $(0.000111)$ \\
\hline \multirow[t]{2}{*}{ Undiff*Black } & & 0.000353 & 0.000380 & 0.000214 \\
\hline & & $(0.000342)$ & $(0.000344)$ & $(0.000363)$ \\
\hline \multirow[t]{2}{*}{ Undiff*Hispanic } & & $0.000769^{* * * *}$ & $0.000650^{* * *}$ & $0.000575^{* *}$ \\
\hline & & $(0.000247)$ & $(0.000249)$ & $(0.000261)$ \\
\hline \multirow[t]{2}{*}{ Undiff*Rising } & & & & $0.000527^{* * *}$ \\
\hline & & & & $(0.000105)$ \\
\hline \multirow[t]{2}{*}{ Undiff*Rising*Black } & & & & 0.000425 \\
\hline & & & & $(0.000431)$ \\
\hline \multirow[t]{2}{*}{ Undiff*Rising*Hispanic } & & & & $0.000820^{* * *}$ \\
\hline & & & & $(0.000307)$ \\
\hline Sample size & 863,228 & 863,228 & 863,228 & 863,228 \\
\hline Mean of dependent variable & 0.01713 & 0.01713 & 0.01713 & 0.01713 \\
\hline \multicolumn{5}{|c|}{ Panel B. Linear Regressions for Probability of Unemployment-to-Employment Transition } \\
\hline \multirow[t]{2}{*}{ Black } & $-0.0516^{* * *}$ & $-0.0828^{* * *}$ & $-0.0856^{* * *}$ & $-0.0830^{* * *}$ \\
\hline & $(0.00582)$ & $(0.0124)$ & $(0.0124)$ & $(0.0124)$ \\
\hline \multirow[t]{2}{*}{ Hispanic } & $0.0732^{* * *}$ & $0.0721^{* * *}$ & $0.0902^{* * *}$ & $0.0722^{* * *}$ \\
\hline & $(0.00676)$ & $(0.0134)$ & $(0.0133)$ & $(0.0134)$ \\
\hline \multirow[t]{2}{*}{ Undiff } & $-0.0234^{* * *}$ & $-0.0249^{* * *}$ & $-0.0251^{* * *}$ & $-0.0248^{* * *}$ \\
\hline & $(0.00155)$ & $(0.00170)$ & $(0.00171)$ & $(0.00175)$ \\
\hline \multirow[t]{2}{*}{ Undiff*Black } & & $0.00849^{* * *}$ & $0.00796^{* * *}$ & $0.00764^{* *}$ \\
\hline & & $(0.00285)$ & $(0.00286)$ & $(0.00298)$ \\
\hline \multirow[t]{2}{*}{ Undiff*Hispanic } & & 0.000295 & 0.0000608 & -0.000281 \\
\hline & & $(0.00281)$ & $(0.00285)$ & $(0.00298)$ \\
\hline \multirow[t]{2}{*}{ Undiff*Falling } & & & & -0.000597 \\
\hline & & & & $(0.00124)$ \\
\hline \multirow[t]{2}{*}{ Undiff*Falling*Black } & & & & 0.00263 \\
\hline & & & & $(0.00247)$ \\
\hline \multirow[t]{2}{*}{ Undiff*Falling*Hispanic } & & & & 0.00154 \\
\hline & & & & $(0.00239)$ \\
\hline Sample size & 57,510 & 57,510 & 57,510 & 57,510 \\
\hline Mean of dependent variable & 0.23487 & 0.23487 & 0.23487 & 0.23487 \\
\hline
\end{tabular}

Notes: The sample consists of males aged 25-55 who are in the labor force for any two consecutive months. All estimates are calculated using sample weights provided by the CPS. Standard errors are adjusted for multiple observations per individual. All specifications also included a constant, age, age squared, marital status, education, occupation and industry, and state and month fixed effects except Specification 3, which excludes age, marital status, education, occupation and industry.

${ }^{*} \mathrm{p}<0.1 ; * * \mathrm{p}<0.05 ; * * * \mathrm{p}<0.01$ 


\subsection{Transitions from Unemployment to Employment}

Panel B of Table 3 reports OLS estimates of the LPM for moving from unemployment to employment during the sample period from 1996 to 2012. Specification 1 reports estimates for the base equation, which includes a dummy variable for black and Hispanic along with the business cycle control. Specification 2 includes the interactions between the dummy variable for black or Hispanic and the business cycle control. Results from these two models indicate that blacks are less likely than whites to move from unemployment to employment while Hispanics are more likely than whites to move from unemployment to employment after controlling for education, occupation, industry, and other individual characteristics. The parameter estimates associated with the business cycle variable indicate that all the workers in the sample have less chance of moving from unemployment to employment when demand conditions are weak. The parameter associated with the interaction between the business cycle control variable and the dummy variable for Hispanic is positive and statistically significant showing that Hispanic men are more likely to be reemployed than whites when demand conditions are relatively weak. The parameter associated with the interaction between the business cycle control variable and the dummy for black is positive and statistically insignificant indicating that black men do not differ from white men in their cyclical responsiveness to changes in the tightness of labor markets. For both blacks and Hispanics there are no findings over the full sample period that suggest minority groups are last hired throughout the business cycle. ${ }^{11}$

Specification 3 again excludes the controls for personal and job characteristics. By contrasting the results with those in Specification 2, it can be seen that the exclusion of those controls has little impact on the reported parameter estimates. Specification 4 includes an interaction between the business cycle control variable, a dummy variable for whether it is a period of falling aggregate unemployment, and the dummy variable

\footnotetext{
${ }^{11}$ In another set of regressions, we exclude the self-employed people from the employed workers, and blacks are found to be more likely to be reemployed than whites while Hispanic workers do not respond differently from white men. The conclusion is again there are no findings supporting the minority groups being last hired throughout the business cycle.
} 
for minority to test whether the unemployment exit rate among minorities responds more strongly when the labor market is in a period of growing demand. Since the relevant interaction terms are statistically insignificant, there is no evidence that minorities have a different degree of responsiveness than white men to periods of falling unemployment in terms of the probability of being reemployed. Thus, the parameter estimates of the association of the business cycle to the probability of moving from unemployment to employment appear to be symmetric during periods of rising and falling aggregate demand.

Panel B of Tables 4 and 5 respectively report similar OLS parameter estimates for the LPM in sample periods prior to the Great Recession and afterwards. Panel B of Table 4 contains estimates for the period from 1996-2007. The parameters associated with the dummy variables for being black or Hispanic (similar to those in Panel B of Table 3) show that blacks are less likely to be reemployed and Hispanics are more likely to be reemployed in the following month. In specifications (3) and (4), similar to the entire sample, Hispanics are found to be more likely to transition from unemployment to employment when business cycle conditions are weak while blacks do not have a differential responsiveness to business cycle conditions relative to whites. Also, there is no evidence of differential responsiveness of blacks or Hispanics to periods of rising or falling unemployment. Thus, in the period of the sample prior to the Great Recession, there is no evidence that blacks or Hispanics are hired later in a business cycle recovery than whites in response to improving demand conditions.

Panel B of Table 5 reports the estimation results for the unemployment exit rate from 2008 to 2012. The base transition probabilities (parameters for the black and Hispanic dummies) remain similar for blacks and Hispanics in comparison to the earlier sample period (Panel B Table 4). The interaction between the business cycle control variable and the dummy for blacks is positive and statistically significant across specifications (2), (3), and (4) which indicates that blacks are hired more quickly when demand conditions are weak. This result is inconsistent with the last hired hypothesis. Also, across specifications (2), (3), and (4) there is no evidence of a differential 
responsiveness of Hispanics to business cycle conditions in making the transition from unemployment to employment than whites. There is also no evidence in specification (4) that blacks and Hispanics respond stronger to business cycles in periods of falling unemployment.

For all the above estimates related to the transition from unemployment to employment, the last hired hypothesis is not supported when comparing blacks or Hispanics to whites either in the entire sample or the two sub-periods examined. On the other hand, black men actually had a higher probability of being reemployed in the sample period after the Great Recession, and Hispanics were more likely to be reemployed than whites in the sample period of 1996-2012.

\section{Empirical Results for Transitions into and out of the Labor Force \\ 6.1 Monthly Transition Probabilities}

The last hired, first fired hypothesis cannot be fully examined without considering transitions involved with nonparticipation in the labor force. As the economy worsens, it is likely that an increasing portion of the labor force would move directly from being employed to nonparticipation. Also as the economy recovers, it is more likely that the probability of movement from nonparticipation to employment would rise. Here the analysis is expanded to include movements into and out of the labor force. Figure 4 shows the pattern of the proportion of the civilian population older than 16 NILF (Not in the Labor Force) over the sample period of 1996-2012. The NILF rates are relatively stable for all the racial groups over the sample years, as compared with the unemployment rates in Figure 1, and the unemployment entry and exit rates in Figures 2 and 3. Black workers are more likely to be NILF than Hispanic or white workers, with group rates for blacks ranging roughly from 15 to 20 percent. The proportions NILF for Hispanic and white men range from about 7 to 10 percent over the sample period. Thus, this suggests that the additional margin of being out of the labor force may be important in considering disaggregated transitions, particularly for blacks.

Table 6 provides a preview of monthly transition probabilities between employment, unemployment, and nonparticipation of blacks, Hispanics, and whites over the entire sample period from 1996-2012. These figures were tabulated from all of the matched monthly observations of CPS data. The average probability of moving from employment 
to not in the labor force for all males in the sample is 0.011 . This probability is slightly lower for whites and slightly higher for Hispanics. Blacks move from employment to nonparticipation at a much higher rate of 0.021 , almost double the probability for whites and Hispanics. Comparing the transition probabilities of moving from employment to not in the labor force and from employment to unemployment, it can be seen that there is a roughly same likelihood between the two for blacks and whites $(0.021$ and 0.020 for blacks; 0.009 and 0.011 for whites). For Hispanics, these two probabilities are .016 and .021 respectively - closer to those of blacks than whites. Thus, it would be an important omission to exclude the transition from employment to not in the labor force from the analysis.

Another important transition in interpreting the racial differences in labor force behavior over the business cycle is the movement from not in the labor force directly to employment. Hispanics are more likely than whites and blacks to move from nonparticipation to employment the following month: $14 \%$ of Hispanic men move from not in the labor force to employment monthly compared with $8 \%$ of white and black men. Comparing

the probability of moving from not in the labor force to employment and the probability of moving from unemployment to employment, the transition from being out of the labor force accounts for about half of all entry into employment. Thus, it is also important to include this transition in explaining hiring patterns.

To provide descriptive evidence of the changes in transition rates before and after the Great Recession, Table 7 provides tabulations constructed in the same way as those presented in Table 6 for the periods of the sample prior to the Great Recession and afterwards. Comparing the pre- and post-Great Recession periods, the probability of entering employment directly from out of the labor force decreased from $8.3 \%$ to $6.5 \%$ for blacks, $8.6 \%$ to $6.9 \%$ for whites, and $15 \%$ to $12.5 \%$ for Hispanics. These reduced prospects of moving from nonparticipation to employment in addition to the smaller probabilities of moving from unemployment to employment already documented in Table 1 contribute to the drop in re-employment that is a key factor in 
Figure 4. Seasonally Adjusted Monthly NILF (Not in the Labor Force) Rates by Race for Men Aged 25-55: Current Population Surveys, 1996-2012

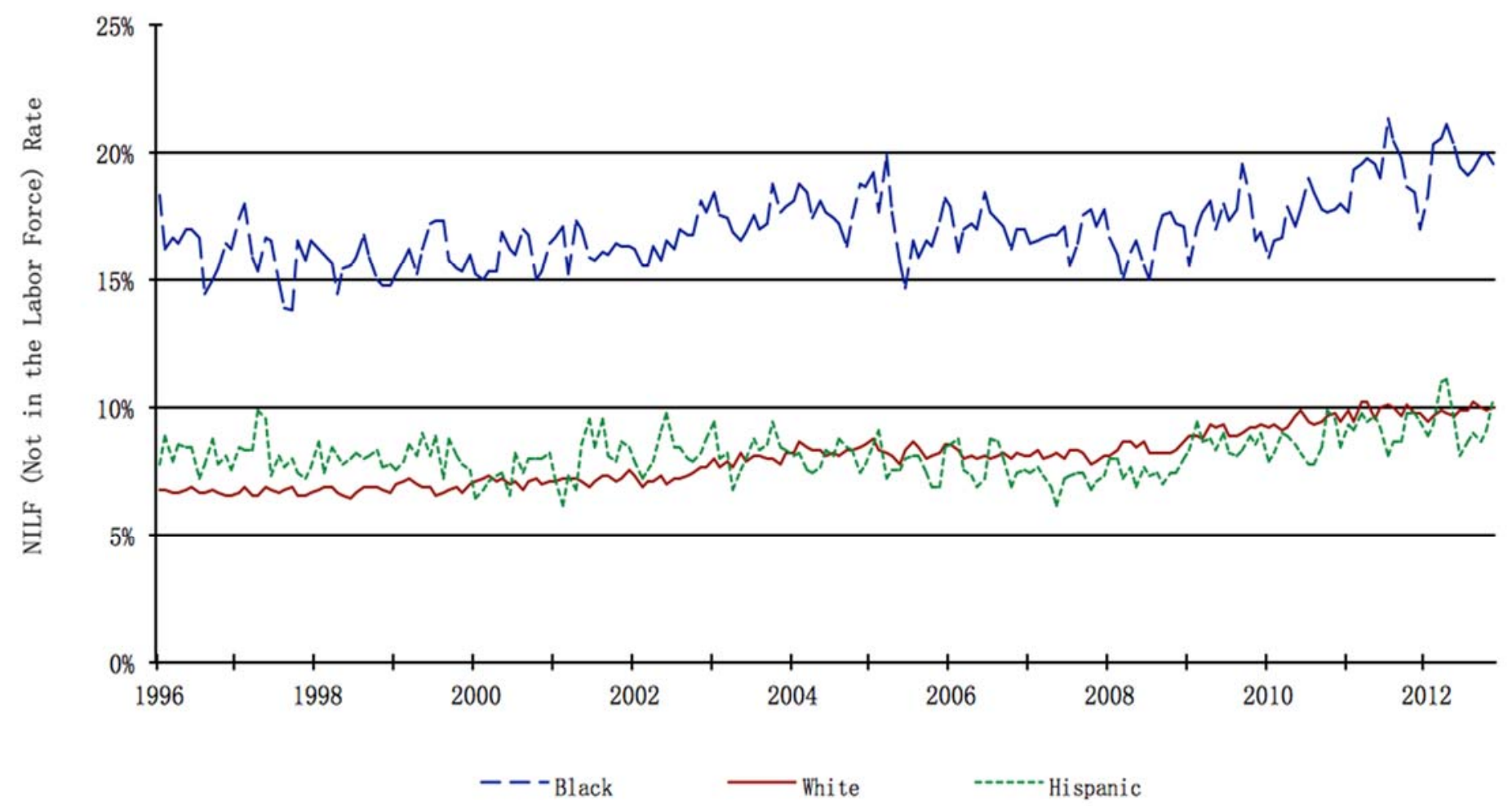


Table 6. Monthly Transition Probabilities: Matched Current Population Surveys, 1996-2012

Status Next Month

\begin{tabular}{lccc} 
& & & Not in the Labor \\
\cline { 2 - 4 } Sample and Status This Month & Employed & Unemployed & \\
\hline Males Aged 25-55 & & & \\
Employed & 0.9758 & 0.013 & 0.0112 \\
Unemployed & 0.2584 & 0.6013 & 0.1402 \\
Not in the Labor Force & 0.0874 & 0.0603 & 0.8523 \\
Black Males Aged 25-55 & & & \\
Employed & 0.9585 & 0.0204 & 0.0212 \\
Unemployed & 0.1979 & 0.6122 & 0.1899 \\
Not in the Labor Force & 0.0769 & 0.0719 & 0.8512 \\
White Males Aged 25-55 & & & \\
Employed & 0.9804 & 0.0106 & 0.009 \\
Unemployed & 0.2583 & 0.6147 & 0.1271 \\
Not in the Labor Force & 0.0803 & 0.0538 & 0.8659 \\
Hispanic Males Aged 25-55 & & & \\
Employed & 0.9639 & 0.0206 & 0.0155 \\
Unemployed & 0.322 & 0.5479 & 0.1302 \\
Not in the Labor Force & 0.1401 & 0.077 & 0.7829 \\
\hline $\begin{array}{l}\text { Notes: The sample consists of males aged 25-55. All estimates are calculated using sample weights provided } \\
\text { by the CPS. }\end{array}$ & &
\end{tabular}


Table 7. Monthly Transition Probabilities: Matched Current Population Surveys

1996-2007

\begin{tabular}{|c|c|c|c|}
\hline \multirow[b]{2}{*}{ Sample and Status This Month } & \multicolumn{3}{|c|}{ Status Next Month } \\
\hline & Employed & Unemployed & $\begin{array}{l}\text { Not in the Labor } \\
\text { Force }\end{array}$ \\
\hline \multicolumn{4}{|l|}{ Males Aged 25-55 } \\
\hline Employed & 0.9776 & 0.0115 & 0.011 \\
\hline Unemployed & 0.3048 & 0.5479 & 0.1472 \\
\hline Not in the Labor Force & 0.0932 & 0.0521 & 0.8548 \\
\hline \multicolumn{4}{|l|}{ Black Males Aged 25-55 } \\
\hline Employed & 0.9604 & 0.0187 & 0.021 \\
\hline Unemployed & 0.2427 & 0.5556 & 0.2017 \\
\hline Not in the Labor Force & 0.0831 & 0.0619 & 0.855 \\
\hline \multicolumn{4}{|l|}{ White Males Aged 25-55 } \\
\hline Employed & 0.9817 & 0.0095 & 0.0088 \\
\hline Unemployed & 0.3062 & 0.5632 & 0.1306 \\
\hline Not in the Labor Force & 0.0861 & 0.0473 & 0.8665 \\
\hline \multicolumn{4}{|l|}{ Hispanic Males Aged 25-55 } \\
\hline Employed & 0.9672 & 0.0173 & 0.0155 \\
\hline Unemployed & 0.3747 & 0.4826 & 0.1427 \\
\hline Not in the Labor Force & 0.1496 & 0.0637 & 0.7867 \\
\hline \multicolumn{4}{|l|}{ 2008-2012 } \\
\hline \multicolumn{4}{|l|}{ Males Aged 25-55 } \\
\hline Employed & 0.9712 & 0.0169 & 0.0118 \\
\hline Unemployed & 0.2032 & 0.6648 & 0.132 \\
\hline Not in the Labor Force & 0.0761 & 0.0764 & 0.8475 \\
\hline \multicolumn{4}{|l|}{ Black Males Aged 25-55 } \\
\hline Employed & 0.9538 & 0.0246 & 0.0217 \\
\hline Unemployed & 0.1423 & 0.6823 & 0.1753 \\
\hline Not in the Labor Force & 0.0646 & 0.0918 & 0.8436 \\
\hline \multicolumn{4}{|l|}{ White Males Aged 25-55 } \\
\hline Employed & 0.9769 & 0.0135 & 0.0096 \\
\hline Unemployed & 0.1979 & 0.6795 & 0.1226 \\
\hline Not in the Labor Force & 0.0688 & 0.0666 & 0.8647 \\
\hline \multicolumn{4}{|l|}{ Hispanic Males Aged 25-55 } \\
\hline Employed & 0.9578 & 0.0267 & 0.0154 \\
\hline Unemployed & 0.2736 & 0.6078 & 0.1186 \\
\hline Not in the Labor Force & 0.1249 & 0.0982 & 0.7769 \\
\hline
\end{tabular}

Notes: The sample consists of males aged 25-55. All estimates are calculated using sample weights provided by the CPS 
increasing aggregate unemployment among all groups in the post-Great Recession period.

It is obvious that the employment situation before the Great Recession period is better than afterwards; however, in the later period the increase in the exit from employment occurs mostly in the movement from employment to unemployment rather than the movement from employment to not in the labor force. This suggests that those who became unemployed had a stronger attachment to the labor market. Comparing the transitions from employment to nonparticipation for blacks, whites, and Hispanics, there is not much difference between the pre- and post-Great Recession period (0.021 and 0.022 for blacks; 0.009 and 0.010 for whites; 0.016 and 0.015 for Hispanics). This indicates that most people who exit from employment become unemployed instead of leaving the labor force.

\subsection{Estimated Transitions across Labor Force States}

To examine whether the movement into and out of the labor force would alter or reinforce the evidence presented in Section 5 regarding the last hired, first fired hypothesis, in this section transitions between all three labor force states are examined (employment, unemployment, NILF). Panel A of Table 8 reports OLS estimates of the possible transitions in a transition probability matrix from LPM across the three labor force states for the whole sample period 1996-2012. All specifications include the dummy variable for black, Hispanic, the business cycle control, and their interactions, comparable to Specification 2 in Table 3. Appendix Tables A.4, A.5, and A.6 provide descriptive statistics for the dependent and independent variables used in carrying out these estimates for the full sample, the pre-recessionary and post-recessionary periods respectively.

In Panel A of Table 8, the OLS coefficients obtained from the LPM for the transition from employment to unemployment are similar to those reported in Panel A of Table 3. For both blacks and Hispanics, the coefficients (Undiff*Black and Undiff*Hispanic) are small, positive, and statistically significant, confirming minorities being more sensitive to the business cycle than whites. The regression coefficients 
(Undiff*Black and Undiff*Hispanic) for the transition from employment to nonparticipation are statistically insignificant for both blacks and Hispanics, providing no evidence of apparent relationship with the business cycle. Combining the evidence regarding different routes of leaving employment, it confirms that minorities have a stronger cyclical response to the business cycle than whites. Results from the inclusion of transitions across all labor force states are consistent with minorities being first fired, i.e. being more likely to exit employment when demand conditions weaken. Column 3 in Table 8 Panel A reports the OLS estimates of the LPM for moving from unemployment to employment, similar to those in Panel B of Table 3. Both blacks and Hispanics have a higher rate of transition from unemployment into employment than whites when demand conditions are relatively weak. The racial differences in the transition rate is unchanged for Hispanics compared to the estimate when only two labor force states are considered while the coefficient for blacks become larger and statistically significant. ${ }^{12}$ The findings from the unemployment to employment transition are consistent with minorities being first hired during periods of growth. When considering the movement from nonparticipation to employment, there is no apparent evidence from the OLS estimates of Hispanics being more sensitive to business cycle conditions than whites. However, black men appear to have a differential response to the business cycle relative to white men. When business cycle conditions are poor, black men are less likely to move from nonparticipation to employment, which partially offsets the positive coefficient in the unemployment-to-employment transition. The overall effect for blacks entering employment would be attenuated by this effect but the combined effect of the estimate parameters of moving into employment from either being unemployed or out of the labor force would be positive, consistent with the

\footnotetext{
${ }^{12}$ Similar to the two-way transitions in Section 5, we run another set of estimates in the three-way transition model here, excluding the self-employed workers. In this set of alternative estimates, Hispanic workers do not respond significantly different to the business cycle conditions than white workers in terms of the unemployment to employment transitions. The lost of significance in the unemployment to employment transition when excluding the self-employed workers indicates that many unemployed Hispanic workers choose to open a business on their own rather than staying unemployed.
} 
interpretation that blacks are more likely to be hired when demand is weak over the entire sample examined.

Panels B and C of Table 8 include variables capturing periods of rising and falling unemployment, respectively, and interactions with the race dummy and the business cycle control. These specifications are used to test whether the transition probabilities are symmetric over the business cycle. With very few significant results in the newly adding interaction terms, the evidence supports symmetric movements in transition rates in periods of rising or falling unemployment.

Panel A of Table 9 provides a set of OLS estimates from a LPM comparable to those in Table 8 but instead focuses on the pre-Great Recession period from 1996 to 2007. For movements out of employment, the estimates reveal a similar pattern to those observed in Table 8 with both blacks and Hispanics experiencing a higher probability of transitioning from employment to unemployment when local demand conditions are weak. Again, the evidence reinforces the assertion that minorities are the first fired when the economy is slack. Turning to movements into employment, column 5 of Panel A shows that black men are less likely to move from nonparticipation to employment in the following month when the unemployment rate is increasing while Hispanic men are more likely to move from nonparticipation to employment than whites. The movement directly from nonparticipation to employment is different in the sample period before the Great Recession with blacks having a lower probability of being reemployed when unemployment is high while Hispanics are more likely to be reemployed. Panels B and C of Table 9 again provide estimates that allow for a test for a symmetric response over the business cycle. As was found in Table 8, there is no appreciable evidence of a differential response in making the transitions examined in periods of rising or falling unemployment.

Table 10 provides additional OLS estimates of the LPM focusing on the sample period after the start of the Great Recession, from 2008 to 2012. For blacks, the parameters associated with leaving employment do not show a different response than whites to business cycle conditions. For Hispanics, there is a pro-cyclical response to 
weak economic conditions in terms of the probability of moving from employment to unemployment. Compared to the pre-Great Recession period when both blacks and 


\begin{tabular}{|c|c|c|c|c|c|c|}
\hline \multirow[b]{2}{*}{ Regressor } & \multicolumn{6}{|c|}{ Transition } \\
\hline & $\begin{array}{l}\text { Employed to } \\
\text { Unemployed }\end{array}$ & $\begin{array}{l}\text { Employed to } \\
\text { Not in Labor } \\
\text { Force }\end{array}$ & $\begin{array}{l}\text { Unemployed } \\
\text { to Employed }\end{array}$ & $\begin{array}{l}\text { Unemployed } \\
\text { to Not in } \\
\text { Labor Force }\end{array}$ & $\begin{array}{c}\text { Not in } \\
\text { Labor Force } \\
\text { to Employed }\end{array}$ & $\begin{array}{l}\text { Not in Labor } \\
\text { Force to } \\
\text { Unemployed }\end{array}$ \\
\hline \multicolumn{7}{|c|}{$\begin{array}{l}\text { Panel A. Linear Regressions Assuming Symmetric Responses Over the Business Cycle Transition } \\
\end{array}$} \\
\hline Black & $\begin{array}{l}0.00896^{* * *} \\
(0.000344)\end{array}$ & $\begin{array}{c}0.0106^{* * *} \\
(0.000361)\end{array}$ & $\begin{array}{l}-0.0629^{* * *} \\
(0.00453)\end{array}$ & $\begin{array}{l}0.0498^{* * *} \\
(0.00390)\end{array}$ & $\begin{array}{c}0.000929 \\
(0.00182)\end{array}$ & $\begin{array}{l}0.0150^{* * *} \\
(0.00153)\end{array}$ \\
\hline Hispanic & $\begin{array}{l}0.00209^{* * *} \\
(0.000307)\end{array}$ & $\begin{array}{l}0.00234^{* * *} \\
(0.000293)\end{array}$ & $\begin{array}{l}0.0529^{* * *} \\
(0.00552)\end{array}$ & $\begin{array}{l}-0.00156 \\
(0.00393)\end{array}$ & $\begin{array}{l}0.0555^{* * *} \\
(0.00288)\end{array}$ & $\begin{array}{c}0.00923^{* * * *} \\
(0.00196)\end{array}$ \\
\hline Undiff & $\begin{array}{c}0.00121^{* * *} \\
(0.0000467)\end{array}$ & $\begin{array}{l}0.000187^{* * *} \\
(0.0000395)\end{array}$ & $\begin{array}{l}-0.0282^{* * *} \\
(0.000699)\end{array}$ & $\begin{array}{c}-0.00417^{* * * *} \\
(0.000541)\end{array}$ & $\begin{array}{l}-0.00389^{* * *} \\
(0.000338)\end{array}$ & $\begin{array}{l}0.00557^{* * *} \\
(0.000317)\end{array}$ \\
\hline Undiff*Black & $\begin{array}{c}0.000660^{* * * *} \\
(0.000180)\end{array}$ & $\begin{array}{c}-0.000000446 \\
(0.000171)\end{array}$ & $\begin{array}{l}0.00417^{* * *} \\
(0.00137)\end{array}$ & $\begin{array}{l}-0.00202 \\
(0.00129)\end{array}$ & $\begin{array}{l}-0.00137^{* *} \\
(0.000674)\end{array}$ & $\begin{array}{l}0.00238^{* * *} \\
(0.000746)\end{array}$ \\
\hline Undiff*Hispanic & $\begin{array}{l}0.00116^{* * *} \\
(0.000140)\end{array}$ & $\begin{array}{l}-0.000114 \\
(0.000108)\end{array}$ & $\begin{array}{l}0.00351^{* * *} \\
(0.00149)\end{array}$ & $\begin{array}{l}-0.000937 \\
(0.00107)\end{array}$ & $\begin{array}{l}-0.000809 \\
(0.00102)\end{array}$ & $\begin{array}{l}0.00441^{* * * *} \\
(0.000892)\end{array}$ \\
\hline $\mathrm{N}$ & $3,184,345$ & $3,184,345$ & 152,433 & 152,433 & 322,671 & 322,671 \\
\hline$R^{2}$ & 0.009 & 0.006 & 0.045 & 0.015 & 0.026 & 0.017 \\
\hline \multicolumn{7}{|c|}{ Panel B. Linear Regressions Testing Symmetric Response Over the Business Cycle } \\
\hline Black & $\begin{array}{l}0.00896^{* * *} \\
(0.000344)\end{array}$ & $\begin{array}{c}0.0106^{* * *} \\
(0.000361)\end{array}$ & $\begin{array}{l}-0.0629^{* * *} \\
(0.00453)\end{array}$ & $\begin{array}{l}0.0498^{* * *} \\
(0.00390)\end{array}$ & $\begin{array}{c}0.000925 \\
(0.00182)\end{array}$ & $\begin{array}{l}0.0151^{* * *} \\
(0.00153)\end{array}$ \\
\hline Hispanic & $\begin{array}{l}0.00207^{* * *} \\
(0.000307)\end{array}$ & $\begin{array}{l}0.00234^{* * *} \\
(0.000293)\end{array}$ & $\begin{array}{l}0.0531^{* * * *} \\
(0.00552)\end{array}$ & $\begin{array}{l}-0.00146 \\
(0.00393)\end{array}$ & $\begin{array}{l}0.0555^{* * *} \\
(0.00289)\end{array}$ & $\begin{array}{l}0.00918^{* * * *} \\
(0.00196)\end{array}$ \\
\hline Undiff & $\begin{array}{c}0.00107^{* * *} \\
(0.0000549)\end{array}$ & $\begin{array}{l}0.000171^{* * *} \\
(0.0000468)\end{array}$ & $\begin{array}{l}-0.0288^{* * * *} \\
(0.000779)\end{array}$ & $\begin{array}{l}-0.00317^{* * * *} \\
(0.000632)\end{array}$ & $\begin{array}{l}-0.00394^{* * *} \\
(0.000391)\end{array}$ & $\begin{array}{c}0.00485^{* * *} \\
(0.000367)\end{array}$ \\
\hline Undiff*Black & $\begin{array}{l}0.000531^{* *} \\
(0.000213)\end{array}$ & $\begin{array}{c}0.00000437 \\
(0.000209)\end{array}$ & $\begin{array}{l}0.00488^{* * *} \\
(0.00153)\end{array}$ & $\begin{array}{c}-0.00318^{* *} \\
(0.00152)\end{array}$ & $\begin{array}{c}-0.00199^{* * *} \\
(0.000773)\end{array}$ & $\begin{array}{l}0.00333^{* * *} \\
(0.000885)\end{array}$ \\
\hline Undiff*Hispanic & $\begin{array}{c}0.000907^{* * * *} \\
(0.000163)\end{array}$ & $\begin{array}{l}-0.0000895 \\
(0.000126)\end{array}$ & $\begin{array}{c}0.00472^{* * *} \\
(0.00164)\end{array}$ & $\begin{array}{c}-0.00166 \\
(0.00120)\end{array}$ & $\begin{array}{l}0.000282 \\
(0.00116)\end{array}$ & $\begin{array}{l}0.00453^{* * * 4} \\
(0.00102)\end{array}$ \\
\hline Undiff*Rising & $\begin{array}{l}0.000383^{* * *} \\
(0.0000869)\end{array}$ & $\begin{array}{c}0.0000459 \\
(0.0000731)\end{array}$ & $\begin{array}{c}0.00153 \\
(0.00102)\end{array}$ & $\begin{array}{l}-0.00280^{* * * *} \\
(0.000834)\end{array}$ & $\begin{array}{c}0.000147 \\
(0.000558)\end{array}$ & $\begin{array}{l}0.00211^{* * * *} \\
(0.000579)\end{array}$ \\
\hline Undiff*Rising*Black & $\begin{array}{c}0.000378 \\
(0.000365)\end{array}$ & $\begin{array}{c}-0.0000133 \\
(0.000325)\end{array}$ & $\begin{array}{c}-0.00198 \\
(0.00212)\end{array}$ & $\begin{array}{c}0.00325 \\
(0.00217)\end{array}$ & $\begin{array}{c}0.00183 \\
(0.00117)\end{array}$ & $\begin{array}{c}-0.00276^{* *} \\
(0.00136)\end{array}$ \\
\hline Undiff*Rising*Hispanic & $\begin{array}{c}0.000789^{* * * *} \\
(0.000277)\end{array}$ & $\begin{array}{l}-0.0000721 \\
(0.000205)\end{array}$ & $\begin{array}{l}-0.00370^{*} \\
(0.00221)\end{array}$ & $\begin{array}{c}0.00192 \\
(0.00164)\end{array}$ & $\begin{array}{l}-0.00340^{* * *} \\
(0.00165)\end{array}$ & $\begin{array}{l}-0.000203 \\
(0.00162)\end{array}$ \\
\hline $\mathrm{N}$ & $3,184,345$ & $3,184,345$ & 152,433 & 152,433 & 322,671 & 322,671 \\
\hline$R^{2}$ & 0.009 & 0.006 & 0.045 & 0.015 & 0.026 & 0.017 \\
\hline \multicolumn{7}{|c|}{ Panel C. Linear Regressions Testing Symmetric Response Over the Business Cycle } \\
\hline Black & $\begin{array}{l}0.00896^{* * *} \\
(0.000344)\end{array}$ & 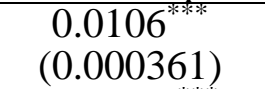 & $\begin{array}{l}-0.0629^{* * *} \\
(0.00453)\end{array}$ & $\begin{array}{l}0.0498^{* * *} \\
(0.00390)\end{array}$ & $\begin{array}{l}0.000926 \\
(0.00182)\end{array}$ & $\begin{array}{l}0.0150^{* * *} \\
(0.00153)\end{array}$ \\
\hline Hispanic & $\begin{array}{l}0.00208^{* * *} \\
(0.000307)\end{array}$ & $\begin{array}{l}0.00234^{* * *} \\
(0.000293)\end{array}$ & $\begin{array}{l}0.0530^{* * *} \\
(0.00552)\end{array}$ & $\begin{array}{l}-0.00156 \\
(0.00393)\end{array}$ & $\begin{array}{l}0.0555^{* * *} \\
(0.00288)\end{array}$ & $\begin{array}{l}0.00921^{* * * *} \\
(0.00196)\end{array}$ \\
\hline Undiff & $\begin{array}{c}0.00131^{* * *} \\
(0.0000562)\end{array}$ & $\begin{array}{l}0.000178^{* * *} \\
(0.0000474)\end{array}$ & $\begin{array}{l}-0.0279^{* * *} \\
(0.000787)\end{array}$ & $\begin{array}{l}-0.00489^{* * *} \\
(0.000610)\end{array}$ & $\begin{array}{l}-0.00358^{* * *} \\
(0.000392)\end{array}$ & $\begin{array}{l}0.00599^{* * * *} \\
(0.000380)\end{array}$ \\
\hline Undiff*Black & $\begin{array}{c}0.000625^{* * *} \\
(0.000220)\end{array}$ & $\begin{array}{l}0.0000205 \\
(0.000204)\end{array}$ & $\begin{array}{c}0.00293^{*} \\
(0.00157)\end{array}$ & $\begin{array}{l}-0.000685 \\
(0.00148)\end{array}$ & $\begin{array}{l}-0.00164^{* * 3} \\
(0.000789)\end{array}$ & $\begin{array}{c}0.00203^{* *} \\
(0.000889)\end{array}$ \\
\hline Undiff*Hispanic & $\begin{array}{l}0.00134^{* * *} \\
(0.000173)\end{array}$ & $\begin{array}{l}-0.000201 \\
(0.000130)\end{array}$ & $\begin{array}{c}0.00265 \\
(0.00170)\end{array}$ & $\begin{array}{l}0.000368 \\
(0.00123)\end{array}$ & $\begin{array}{l}-0.00144 \\
(0.00119)\end{array}$ & $\begin{array}{l}0.00446^{* * *} \\
(0.00108)\end{array}$ \\
\hline Undiff*Falling & $\begin{array}{c}-0.000283^{* * *} \\
(0.0000864)\end{array}$ & $\begin{array}{c}0.0000262 \\
(0.0000730)\end{array}$ & $\begin{array}{l}-0.000802 \\
(0.00104)\end{array}$ & $\begin{array}{c}0.00214^{* * *} \\
(0.000882)\end{array}$ & $\begin{array}{l}-0.000864 \\
(0.000560)\end{array}$ & $\begin{array}{l}-0.00118^{* *} \\
(0.000563)\end{array}$ \\
\hline Undiff*Falling*Black & $\begin{array}{l}0.0000973 \\
(0.000351)\end{array}$ & $\begin{array}{c}-0.0000586 \\
(0.000333)\end{array}$ & $\begin{array}{c}0.00359^{*} \\
(0.00207)\end{array}$ & $\begin{array}{l}-0.00390 * \\
(0.00216)\end{array}$ & $\begin{array}{l}0.000760 \\
(0.00114)\end{array}$ & $\begin{array}{l}0.000989 \\
(0.00135)\end{array}$ \\
\hline Undiff*Falling*Hispanic & $\begin{array}{l}-0.000486^{*} \\
(0.000263)\end{array}$ & $\begin{array}{c}0.000231 \\
(0.000200)\end{array}$ & $\begin{array}{c}0.00236 \\
(0.00213)\end{array}$ & $\begin{array}{c}-0.00365^{* *} \\
(0.00161)\end{array}$ & $\begin{array}{c}0.00168 \\
(0.00163)\end{array}$ & $\begin{array}{c}-0.0000199 \\
(0.00154)\end{array}$ \\
\hline $\mathrm{N}$ & $3,184,345$ & $3,184,345$ & 152,433 & 152,433 & 322,671 & 322,671 \\
\hline$R^{2}$ & 0.009 & 0.006 & 0.045 & 0.015 & 0.026 & 0.017 \\
\hline
\end{tabular}

Notes: The sample consists of males aged 25-55. All estimates are calculated using sample weights provided by the CPS. Standard errors are adjusted for multiple observations per individual. All specifications also included a constant, age, age squared, marital status, education, occupation and industry, and state and month fixed effects. ${ }^{*} \mathrm{p}<0.1 ; * * \mathrm{p}<0.05 ; * * * \mathrm{p}<0.01$ 


\begin{tabular}{|c|c|c|c|c|c|c|}
\hline \multirow[b]{2}{*}{ Regressor } & \multicolumn{6}{|c|}{ Transition } \\
\hline & $\begin{array}{l}\text { Employed to } \\
\text { Unemployed }\end{array}$ & $\begin{array}{l}\text { Employed } \\
\text { to Not in } \\
\text { Labor Force }\end{array}$ & $\begin{array}{l}\text { Unemployed } \\
\text { to Employed }\end{array}$ & $\begin{array}{l}\text { Unemployed } \\
\text { to Not in } \\
\text { Labor Force }\end{array}$ & $\begin{array}{l}\text { Not in Labor } \\
\text { Force to } \\
\text { Employed }\end{array}$ & $\begin{array}{l}\text { Not in Labor } \\
\text { Force to } \\
\text { Unemployed }\end{array}$ \\
\hline \multicolumn{7}{|c|}{ Panel A. Linear Regressions Assuming Symmetric Responses Over the Business Cycle Transition } \\
\hline Black & $\begin{array}{l}0.00908^{\text {*** }} \\
(0.000425)\end{array}$ & $\begin{array}{c}0.0107^{* * *} \\
(0.000428)\end{array}$ & $\begin{array}{l}-0.0593^{* * *} \\
(0.00519)\end{array}$ & $\begin{array}{l}0.0522^{\text {**** }} \\
(0.00448)\end{array}$ & $\begin{array}{c}-0.000342 \\
(0.00206)\end{array}$ & $\begin{array}{l}0.0145^{* * *} \\
(0.00180)\end{array}$ \\
\hline Hispanic & $\begin{array}{l}0.00213^{* * *} \\
(0.000345)\end{array}$ & $\begin{array}{c}0.00274^{* * * *} \\
(0.000337)\end{array}$ & $\begin{array}{l}0.0543^{* * *} \\
(0.00643)\end{array}$ & $\begin{array}{r}-0.000385 \\
(0.00463)\end{array}$ & $\begin{array}{l}0.0580^{* * *} \\
(0.00326)\end{array}$ & $\begin{array}{c}0.00959^{* * *} \\
(0.00222)\end{array}$ \\
\hline Undiff & $\begin{array}{l}0.00146^{* * *} \\
(0.000103)\end{array}$ & $\begin{array}{l}0.000253^{* * * *} \\
(0.0000981)\end{array}$ & $\begin{array}{l}-0.0402^{* * * *} \\
(0.00258)\end{array}$ & $\begin{array}{c}-0.00856^{* * *} \\
(0.00185)\end{array}$ & $\begin{array}{c}-0.00326^{* * * *} \\
(0.00102)\end{array}$ & $\begin{array}{l}0.00642^{* * * *} \\
(0.000763)\end{array}$ \\
\hline Undiff*Black & $\begin{array}{l}0.00118^{* * *} \\
(0.000359)\end{array}$ & $\begin{array}{l}0.0000971 \\
(0.000371)\end{array}$ & $\begin{array}{c}0.00414 \\
(0.00466)\end{array}$ & $\begin{array}{c}-0.00211 \\
(0.00412)\end{array}$ & $\begin{array}{c}-0.00532^{* * *} \\
(0.00178)\end{array}$ & $\begin{array}{c}0.00182 \\
(0.00156)\end{array}$ \\
\hline Undiff*Hispanic & $\begin{array}{l}0.00124^{* * *} \\
(0.000310)\end{array}$ & $\begin{array}{c}0.000196 \\
(0.000286)\end{array}$ & $\begin{array}{c}0.00907 \\
(0.00555)\end{array}$ & $\begin{array}{l}-0.000655 \\
(0.00371)\end{array}$ & $\begin{array}{l}0.00682^{* * *} \\
(0.00301)\end{array}$ & $\begin{array}{l}0.00778^{* * *} \\
(0.00206)\end{array}$ \\
\hline $\mathrm{N}$ & $2,311,516$ & $2,311,516$ & 86,434 & 86,434 & 217,833 & 217,833 \\
\hline$R^{2}$ & 0.008 & 0.006 & 0.035 & 0.016 & 0.028 & 0.014 \\
\hline \multicolumn{7}{|c|}{ Panel B. Linear Regressions Testing Symmetric Response Over the Business Cycle } \\
\hline Black & $\begin{array}{l}0.00909^{* * *} \\
(0.000426)\end{array}$ & $\begin{array}{c}0.0107^{* * *} \\
(0.000428)\end{array}$ & $\begin{array}{l}-0.0595^{* * *} \\
(0.00520)\end{array}$ & $\begin{array}{l}0.0523^{* * *} \\
(0.00449)\end{array}$ & $\begin{array}{c}-0.000236 \\
(0.00206)\end{array}$ & $\begin{array}{l}0.0146^{* * *} \\
(0.00180)\end{array}$ \\
\hline Hispanic & $\begin{array}{l}0.00212^{* * *} \\
(0.000345)\end{array}$ & $\begin{array}{c}0.00272^{* * *} \\
(0.000336)\end{array}$ & $\begin{array}{l}0.0544^{* * *} \\
(0.00643)\end{array}$ & $\begin{array}{l}-0.000477 \\
(0.00463)\end{array}$ & $\begin{array}{l}0.0580^{* * *} \\
(0.00326)\end{array}$ & $\begin{array}{l}0.00958^{* * *} \\
(0.00223)\end{array}$ \\
\hline Undiff & $\begin{array}{l}0.00147^{* * *} \\
(0.000113)\end{array}$ & $\begin{array}{c}0.000281^{* * *} \\
(0.000109)\end{array}$ & $\begin{array}{l}-0.0402^{* * *} \\
(0.00292)\end{array}$ & $\begin{array}{l}-0.0107^{* * *} \\
(0.00210)\end{array}$ & $\begin{array}{c}-0.00364^{* * *} \\
(0.00114)\end{array}$ & $\begin{array}{l}0.00621^{* * * *} \\
(0.000845)\end{array}$ \\
\hline Undiff*Black & $\begin{array}{l}0.00113^{* * *} \\
(0.000415)\end{array}$ & $\begin{array}{l}-0.000259 \\
(0.000430)\end{array}$ & $\begin{array}{c}0.00648 \\
(0.00538)\end{array}$ & $\begin{array}{c}-0.00273 \\
(0.00492)\end{array}$ & $\begin{array}{c}-0.00640^{* * *} \\
(0.00207)\end{array}$ & $\begin{array}{c}0.00116 \\
(0.00177)\end{array}$ \\
\hline Undiff*Hispanic & $\begin{array}{l}0.00134^{* * *} \\
(0.000371)\end{array}$ & $\begin{array}{c}0.000539 \\
(0.000341)\end{array}$ & $\begin{array}{c}0.00661 \\
(0.00658)\end{array}$ & $\begin{array}{l}0.000685 \\
(0.00439)\end{array}$ & $\begin{array}{c}0.00686^{*} \\
(0.00352)\end{array}$ & $\begin{array}{l}0.00797^{* * * *} \\
(0.00244)\end{array}$ \\
\hline Undiff*Rising & $\begin{array}{c}-0.0000311 \\
(0.000141)\end{array}$ & $\begin{array}{r}-0.0000847 \\
(0.000139)\end{array}$ & $\begin{array}{c}-0.00000223 \\
(0.00410)\end{array}$ & $\begin{array}{l}0.00686^{* *} \\
(0.00304)\end{array}$ & $\begin{array}{c}0.00123 \\
(0.00153)\end{array}$ & $\begin{array}{l}0.000689 \\
(0.00117)\end{array}$ \\
\hline Undiff*Rising*Black & $\begin{array}{c}0.000166 \\
(0.000667)\end{array}$ & $\begin{array}{c}0.00114 \\
(0.000694)\end{array}$ & $\begin{array}{c}-0.00786 \\
(0.00927)\end{array}$ & $\begin{array}{c}0.00251 \\
(0.00810)\end{array}$ & $\begin{array}{c}0.00357 \\
(0.00330)\end{array}$ & $\begin{array}{c}0.00216 \\
(0.00290)\end{array}$ \\
\hline Undiff*Rising*Hispanic & $\begin{array}{c}-0.000301 \\
(0.000619)\end{array}$ & $\begin{array}{c}-0.00107^{*} \\
(0.000583)\end{array}$ & $\begin{array}{l}0.00779 \\
(0.0106)\end{array}$ & $\begin{array}{c}-0.00418 \\
(0.00755)\end{array}$ & $\begin{array}{l}-0.000154 \\
(0.00564)\end{array}$ & $\begin{array}{c}-0.000604 \\
(0.00406)\end{array}$ \\
\hline $\mathrm{N}$ & $2,311,516$ & $2,311,516$ & 86,434 & 86,434 & 217,833 & 217,833 \\
\hline$R^{2}$ & 0.008 & 0.006 & 0.035 & 0.016 & 0.028 & 0.014 \\
\hline \\
\hline Black & $\begin{array}{l}0.00908^{* * *} \\
(0.000425)\end{array}$ & $\begin{array}{c}0.0107^{* * *} \\
(0.000428)\end{array}$ & $\begin{array}{l}-0.0594^{* * *} \\
(0.00519)\end{array}$ & $\begin{array}{l}0.0523^{* * *} \\
(0.00448)\end{array}$ & $\begin{array}{l}-0.000321 \\
(0.00206)\end{array}$ & $\begin{array}{l}0.0145^{* * *} \\
(0.00180)\end{array}$ \\
\hline Hispanic & $\begin{array}{l}0.00213^{* * *} \\
(0.000345)\end{array}$ & $\begin{array}{l}0.00274^{* * *} \\
(0.000336)\end{array}$ & $\begin{array}{l}0.0544^{* * *} \\
(0.00643)\end{array}$ & $\begin{array}{c}-0.000383 \\
(0.00463)\end{array}$ & $\begin{array}{l}0.0580^{* * * *} \\
(0.00326)\end{array}$ & $\begin{array}{c}0.00955^{* * * *} \\
(0.00222)\end{array}$ \\
\hline Undiff & $\begin{array}{l}0.00139^{* * *} \\
(0.000113)\end{array}$ & $\begin{array}{c}0.000151 \\
(0.000109)\end{array}$ & $\begin{array}{l}-0.0396^{* * *} \\
(0.00299)\end{array}$ & $\begin{array}{c}-0.00750^{* * * *} \\
(0.00214)\end{array}$ & $\begin{array}{l}-0.00212^{*} \\
(0.00116)\end{array}$ & $\begin{array}{c}0.00684^{* * *} \\
(0.000878)\end{array}$ \\
\hline Undiff*Black & $\begin{array}{c}0.00104^{* *} \\
(0.000429)\end{array}$ & $\begin{array}{c}0.000320 \\
(0.000455)\end{array}$ & $\begin{array}{c}0.00104 \\
(0.00580)\end{array}$ & $\begin{array}{l}0.000666 \\
(0.00512)\end{array}$ & $\begin{array}{c}-0.00516^{* *} \\
(0.00213)\end{array}$ & $\begin{array}{l}0.000827 \\
(0.00185)\end{array}$ \\
\hline Undiff*Hispanic & $\begin{array}{l}0.00125^{* * *} \\
(0.000386)\end{array}$ & $\begin{array}{c}0.0000195 \\
(0.000349)\end{array}$ & $\begin{array}{c}0.0132^{* \prime} \\
(0.00677)\end{array}$ & $\begin{array}{c}-0.00265 \\
(0.00461)\end{array}$ & $\begin{array}{l}0.00815^{* *} \\
(0.00360)\end{array}$ & $\begin{array}{l}0.00592^{* * *} \\
(0.00251)\end{array}$ \\
\hline Undiff*Falling & $\begin{array}{c}0.000191 \\
(0.000141)\end{array}$ & $\begin{array}{l}0.000276^{* *} \\
(0.000137)\end{array}$ & $\begin{array}{l}-0.00158 \\
(0.00403)\end{array}$ & $\begin{array}{l}-0.00282 \\
(0.00294)\end{array}$ & $\begin{array}{l}-0.00309^{* *} \\
(0.00149)\end{array}$ & $\begin{array}{l}-0.00111 \\
(0.00111)\end{array}$ \\
\hline Undiff*Falling*Black & $\begin{array}{c}0.000389 \\
(0.000645)\end{array}$ & $\begin{array}{l}-0.000597 \\
(0.000687)\end{array}$ & $\begin{array}{c}0.00804 \\
(0.00864)\end{array}$ & $\begin{array}{l}-0.00720 \\
(0.00786)\end{array}$ & $\begin{array}{c}-0.000448 \\
(0.00319)\end{array}$ & $\begin{array}{c}0.00265 \\
(0.00273)\end{array}$ \\
\hline Undiff*Falling*Hispanic & $\begin{array}{r}-0.0000277 \\
(0.000600)\end{array}$ & $\begin{array}{c}0.000462 \\
(0.000571)\end{array}$ & $\begin{array}{l}-0.0107 \\
(0.0104)\end{array}$ & $\begin{array}{c}0.00518 \\
(0.00732)\end{array}$ & $\begin{array}{c}-0.00356 \\
(0.00541)\end{array}$ & $\begin{array}{c}0.00499 \\
(0.00394)\end{array}$ \\
\hline $\mathrm{N}$ & $2,311,516$ & $2,311,516$ & 86,434 & 86,434 & 217,833 & 217,833 \\
\hline$R^{2}$ & 0.008 & 0.006 & 0.035 & 0.016 & 0.028 & 0.014 \\
\hline
\end{tabular}

\footnotetext{
Notes: The sample consists of males aged 25-55. All estimates are calculated using sample weights provided by the CPS. Standard errors are adjusted for multiple observations per individual. All specifications also included a constant, age, age squared, marital status, education, occupation and industry, and state and month fixed effects. ${ }^{*} \mathrm{p}<0.1 ;{ }^{* *} \mathrm{p}<0.05 ; * * * \mathrm{p}<0.01$
} 


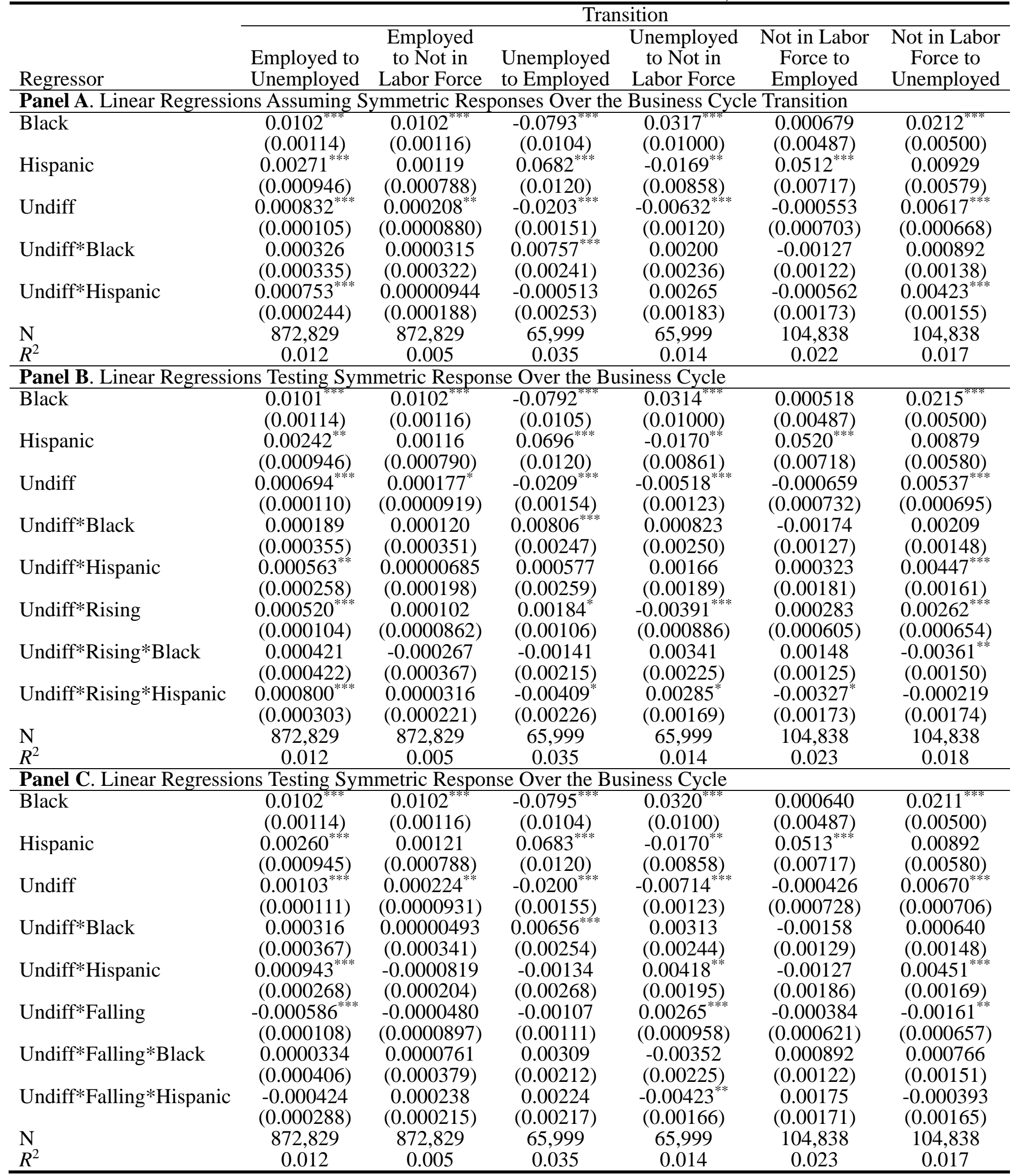

Notes: The sample consists of males aged 25-55. All estimates are calculated using sample weights provided by the CPS. Standard errors are adjusted for multiple observations per individual. All specifications also included a constant, age, age squared, marital status, education, occupation and industry, and state and month fixed effects. ${ }^{*} \mathrm{p}<0.1 ; * * \mathrm{p}<0.05 ; * * * \mathrm{p}<0.01$ 
Hispanics reveal a tendency of being first fired, only the Hispanic group preserves this pattern in the post Great Recession period. For transitions into employment, the last hired hypothesis is not supported for blacks as it was in the sample period prior to the Great Recession. Instead, black men have a higher probability of being reemployed from the labor force (from the unemployed) in the sample period after the Great Recession. For Hispanics there is no pattern indicating that they are last hired. The tests for symmetric response found in Panels C and D provide no evidence of differential responsiveness in making the transitions examined in periods of rising or falling unemployment.

\section{Test of Structural Change before and after the Great Recession}

Table 11 reports changes in estimation parameters from the Linear Probability Model (LPM) in the Great Recession period relative to the entire sample. The tests are performed by interacting every variable in the LPM estimates in Table 3 with a new dummy for observations that are after the start of the Great Recession. Thus, the reported coefficients reflect the changes in relative parameters from the sample period of 1996-2007 to 2008-2013. All specifications include a constant, age, age squared, marital status, education, occupation and industry, and state and month fixed effects except Specification 3, which excludes age, marital status, education, occupation and industry. Standard errors correct for clustering of individual observations.

Panel A reports changes in the OLS estimates of the LPM for the unemployment entry rate from before to after the Great Recession. Specification 1 shows that the blackwhite differential in transition rates increased significantly by 0.26 of a percentage point from the pre-Great Recession period, and that the Hispanic-white differential in transition rates increased significantly by 0.29 of a percentage point from the pre-Great Recession period. The results indicate that minorities experienced a structurally higher probability in moving from employment to unemployment after the initiation of the Great Recession. Compared to the pre-Great Recession period, the heightened probability of blacks (relative to whites) to enter unemployment as demand weakens is 
reduced in the post-Great Recession period, shown by a reduction of 0.08 of a percentage point in Specification 2 and 0.09 of a percentage point in Specification 4. The heightened probability of Hispanics (relative to whites) to enter unemployment as demand conditions weaken is also moderated after the initiation of the Great Recession, shown by a significant decrease of 0.10 of a percentage point in Specification 3 and 0.09 of a percentage point in Specification 4. These estimates demonstrate that the probability of minorities to be laid off increased across the board during the great recession but the cyclical effect was dampened relative to other periods.

Panel B reports whether the OLS parameter estimates for the LPM models for the unemployment exit rate changed significantly from before to after the Great Recession. In terms of moving from unemployment to employment, the black-white differential in transition rates (parameters for the black dummy) decreased significantly from the preGreat Recession period as shown in Specifications 2, 3, and 4, indicating that black men faced an even lower chance (more than 3 percentage points) of moving from unemployment to employment after the Great Recession. There is no evidence that the base probability of being re-employed changed for Hispanics relative to whites or that the cyclical responsiveness of the probability of re-employment changed for minorities during the Great Recession.

In summary, in the two-state model that only considers changes between employment and unemployment, the greatest changes during the Great Recession appeared to be (1) an increase in the probability of becoming unemployed for minorities (blacks and Hispanics) relative to whites along with an attenuation in its cyclical responsiveness and (2) a sizeable (more than 3 percentage points) reduction in the probability of becoming re-employed for blacks.

We also examine changes in the parameter estimates in the three-state model (employment, unemployment, out of the labor force) to see whether significant changes occurred after initiation of the Great Recession. The tests are performed by interacting each variable in the Linear Probability Models in Table 8 with a dummy 
(1) (2) (3) (4)

\begin{tabular}{|c|c|c|c|c|}
\hline \multicolumn{5}{|c|}{ Panel A. Linear Regressions for Probability of Employment-to-Unemployment Transition } \\
\hline Black & $0.00261^{* * *}$ & 0.00110 & 0.000385 & 0.00105 \\
\hline \multirow{3}{*}{ Hispanic } & $(0.000826)$ & $(0.00122)$ & $(0.00123)$ & $(0.00122)$ \\
\hline & $0.00292^{* * *}$ & 0.000428 & $0.00348^{* * *}$ & 0.000163 \\
\hline & $(0.000679)$ & $(0.000989)$ & $(0.000964)$ & (0.000989) \\
\hline \multirow[t]{2}{*}{ Undiff } & $-0.000521^{* * * *}$ & $-0.000409^{* * *}$ & $-0.000447^{* * *}$ & $-0.000591^{* * *}$ \\
\hline & $(0.000118)$ & $(0.000118)$ & $(0.000118)$ & $(0.000132)$ \\
\hline \multirow[t]{2}{*}{ Undiff*Black } & & $-0.000836^{*}$ & -0.000767 & $-0.000912^{*}$ \\
\hline & & (0.000496) & (0.000499) & $(0.000554)$ \\
\hline \multirow[t]{2}{*}{ Undiff*Hispanic } & & -0.000624 & $-0.000961^{* *}$ & $-0.000934^{* *}$ \\
\hline & & (0.000395) & $(0.000398)$ & $(0.000453)$ \\
\hline \multirow[t]{2}{*}{ Undiff*Rising } & & & & $0.000521^{* * *}$ \\
\hline & & & & $(0.000176)$ \\
\hline \multirow[t]{2}{*}{ Undiff*Rising*Black } & & & & 0.000241 \\
\hline & & & & $(0.000805)$ \\
\hline \multirow[t]{2}{*}{ Undiff*Rising*Hispanic } & & & & 0.00114 \\
\hline & & & & (0.000699) \\
\hline Sample size & $3,150,683$ & $3,150,683$ & $3,150,683$ & $3,150,683$ \\
\hline \multicolumn{5}{|c|}{ Panel B. Linear Regressions for Probability of Unemployment-to-Employment Transition } \\
\hline \multirow[t]{2}{*}{ Black } & -0.00306 & $-0.0353^{* * *}$ & $-0.0338^{* *}$ & $-0.0355^{* * *}$ \\
\hline & $(0.00810)$ & $(0.0134)$ & $(0.0133)$ & $(0.0134)$ \\
\hline \multirow[t]{2}{*}{ Hispanic } & 0.00383 & -0.00314 & -0.00582 & -0.00287 \\
\hline & $(0.00921)$ & $(0.0145)$ & $(0.0144)$ & $(0.0145)$ \\
\hline \multirow[t]{2}{*}{ Undiff } & $0.0221^{* * * *}$ & $0.0212^{* * *}$ & $0.0225^{* * *}$ & $0.0201^{* * *}$ \\
\hline & $(0.00234)$ & $(0.00273)$ & $(0.00276)$ & $(0.00321)$ \\
\hline \multirow[t]{2}{*}{ Undiff*Black } & & 0.00877 & 0.00868 & 0.0106 \\
\hline & & $(0.00613)$ & $(0.00618)$ & $(0.00745)$ \\
\hline \multirow[t]{2}{*}{ Undiff*Hispanic } & & -0.00366 & -0.00564 & -0.00760 \\
\hline & & $(0.00663)$ & $(0.00673)$ & $(0.00794)$ \\
\hline \multirow[t]{2}{*}{ Undiff*Falling } & & & & 0.00300 \\
\hline & & & & (0.00459) \\
\hline \multirow[t]{2}{*}{ Undiff*Falling*Black } & & & & -0.00430 \\
\hline & & & & $(0.0105)$ \\
\hline \multirow[t]{2}{*}{ Undiff*Falling*Hispanic } & & & & 0.0101 \\
\hline & & & & $(0.0116)$ \\
\hline Sample size & 131,761 & 131,761 & 131,761 & 131,761 \\
\hline
\end{tabular}

Notes: The sample period covers 1996-2012. The reported coefficients are the changes in parameters for 20082012 relative to the entire sample. The sample consists of males aged 25-55 who are in the labor force for any two consecutive months. All estimates are calculated using sample weights provided by the CPS. Standard errors are adjusted for multiple observations per individual. All specifications also included a constant, age, age squared, marital status, education, occupation and industry, and state and month fixed effects except Specification 3, which excludes age, marital status, education, occupation and industry.

${ }^{*} \mathrm{p}<0.1 ; * * \mathrm{p}<0.05 ; * * * \mathrm{p}<0.01$ 
Transition

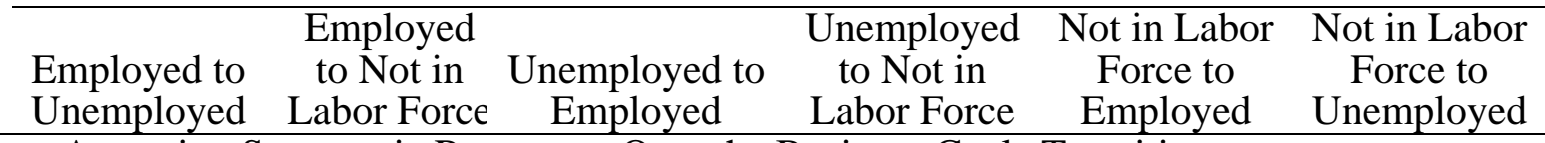

Panel A. Linear Regressions Assuming Symmetric Responses Over the Business Cycle Transition

\begin{tabular}{lcccccc}
\hline Black & .0010798 & .0001054 & $-.0210487^{*}$ & $-.0226343^{* *}$ & .0052039 & .0061431 \\
& $(.0011985)$ & $(.0012188)$ & $(.0112047)$ & $(.0106897)$ & $(.0050838)$ & $(.0051699)$ \\
Hispanic & .0004475 & -.0004243 & .0052524 & $-.0225826^{* *}$ & -.0042519 & -.0000159 \\
& $(.0009745)$ & $(.0008175)$ & $(.0129882)$ & $(.0091557)$ & $(.0074886)$ & $(.0058335)$ \\
Undiff & $-.0004094^{* * *}$ & .0000467 & $.0180516^{* * *}$ & .0001472 & $.0022981^{* *}$ & -.0012632 \\
& $(.0001167)$ & $(.0001043)$ & $(.0024386)$ & $(.001786)$ & $(.001018)$ & $(.0008483)$ \\
Undiff*Black & $-.0008114^{*}$ & -.0001447 & .0039419 & .0049231 & $.0037366^{*}$ & -.0003527 \\
& $(.0004863)$ & $(.0004845)$ & $(.005101)$ & $(.004633)$ & $(.0021034)^{*}$ & $(.0020399)$ \\
Undiff*Hispanic & -.0006085 & -.0002879 & -.0050595 & .0034388 & $-.0072253^{* *}$ & -.0038504 \\
& $(.0003886)$ & $(.0004845)$ & $(.0059785)$ & $(.0040319)$ & $(.0034161)$ & $(.0025352)$ \\
$\mathrm{N}$ & $3,184,345$ & $3,184,345$ & 152,433 & 152,433 & 322,671 & 322,671 \\
$R^{2}$ & 0.0099 & 0.0056 & 0.0469 & 0.0152 & 0.0265 & 0.0173 \\
\hline
\end{tabular}

Panel B. Linear Regressions Testing Symmetric Response Over the Business Cycle

\begin{tabular}{|c|c|c|c|c|c|c|}
\hline Black & $\begin{array}{c}.0010243 \\
(.0011999)\end{array}$ & $\begin{array}{c}.0000993 \\
(.0012183)\end{array}$ & $\begin{array}{l}-.0207284^{*} \\
(.0112188)\end{array}$ & $\begin{array}{c}-.0230345^{* *} \\
(.0106907)\end{array}$ & $\begin{array}{c}.0049534 \\
(.0050864)\end{array}$ & $\begin{array}{c}.006325 \\
(.0051701)\end{array}$ \\
\hline \multirow[t]{2}{*}{ Hispanic } & .0001885 & -.0004228 & .0063767 & $-.0225615^{* *}$ & -.0034297 & -.0003735 \\
\hline & $(.0009748)$ & $(.0008193)$ & $(.0130326)$ & $(.0091835)$ & $(.0074968)$ & $(.0058402)$ \\
\hline \multirow[t]{2}{*}{ Undiff } & $-.0005883^{* * *}$ & -.0000137 & $.0172674^{* * *}$ & $.0037417^{*}$ & $.0027266^{* *}$ & $-.0018025^{*}$ \\
\hline & $(.0001307)$ & $(.0001183)$ & $(.0028046)$ & (.0020592) & 1565) & $(.0009455)$ \\
\hline \multirow{2}{*}{ Undiff*Black } & -.0008929 & .0003029 & .0020192 & .0043847 & $.004318^{* \prime}$ & .0014795 \\
\hline & $(.0005424)$ & (.000549) & $(.0058094)$ & $(.0054276)$ & (.0023798) & $(.0022675)$ \\
\hline \multirow[t]{2}{*}{ Undiff*Hispanic } & $-.0009022^{* *}$ & -.0006305 & -.0016683 & .0009706 & -.0063552 & -.0037495 \\
\hline & $(.0004463)$ & (.000389) & $(.00$ & 819) & $(.0$ & 3878) \\
\hline \multirow{2}{*}{ Undiff*Rising } & $.0005111^{* * *}$ & .0001805 & .0023085 & -.010 & -.00 & 242 \\
\hline & $(.0001745)$ & $(.000$ & $(.00422)$ & $(.00$ & $(.00$ & 3323) \\
\hline \multirow[t]{2}{*}{ Undiff*Rising*Black } & .0002589 & $-.0014074^{*}$ & .0066861 & .0007799 & 412 & $-.0056781^{*}$ \\
\hline & $(.000$ & $(.00$ & $(.00$ & 108) & $(.00$ & 2609) \\
\hline \multirow[t]{2}{*}{ Undiff*Rising*Hispanic } & .001087 & $789^{*}$ & -.011 & .0071841 & -.00 & .0001322 \\
\hline & $(.0006888)$ & $(.0$ & $(.01) \quad$ & $(.00$ & & 201) \\
\hline $\mathrm{N}$ & $3,184,345$ & 3,1 & 152 & & & 671 \\
\hline$R^{2}$ & 0.01 & 0.0056 & 0.047 & 0.0154 & 0.0 & 174 \\
\hline \multicolumn{7}{|c|}{ Panel C. Linear Regressions Testing Symmetric Respo } \\
\hline \multirow[t]{2}{*}{ Black } & .0010808 & .0001004 & $-.0211489^{*}$ & $-.0224481^{* *}$ & .005151 & .0061204 \\
\hline & $(.00$ & & $(.01$ & 78) & $(.005$ & $(.0051701)$ \\
\hline \multirow[t]{2}{*}{ Hispanic } & .0003693 & -.000401 & .005 & $-.0226987^{* *}$ & -.0041634 & -.0002135 \\
\hline & $(.0009742)$ & $(.00$ & $(.01$ & 86) & $(.00$ & $(.0058342)$ \\
\hline \multirow[t]{2}{*}{ Undiff } & -.0001871 & .0001443 & $.0176819^{* * *}$ & 309 & 77 & 1785 \\
\hline & $(.00($ & $(.00$ & 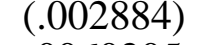 & 98) & $(.00$ & 794) \\
\hline \multirow[t]{2}{*}{ Undiff*Black } & -.0006778 & -.0003929 & .0060 & .003 & .003299 & .0003754 \\
\hline & $(.00$ & $(.00$ & $(.00$ & 09) & $(.00$ & $322)$ \\
\hline \multirow[t]{2}{*}{ Undiff*Hispanic } & -.000414 & -.0002121 & -.0098708 & .0070404 & $-.0092664^{* *}$ & -.0017555 \\
\hline & $(.0004654)_{* * *}$ & $(.0003976)$ & $(.0071826)$ & $(.0049112)$ & 97) & 979) \\
\hline \multirow[t]{2}{*}{ Undiff*Falling } & $-.0006298^{* * * *}$ & -.0002644 & .0009126 & $.0050965^{*}$ & $.0029265^{*}$ & -.0003412 \\
\hline & & $(.00$ & & & & 76) \\
\hline \multirow[t]{2}{*}{ Undiff*Falling*Black } & -.0003556 & .00067 & -.0050037 & .003801 & .001247 & -.0018816 \\
\hline & & $(.0007843)$ & $(.00$ & 99) & $(.00$ & 202) \\
\hline \multirow[t]{2}{*}{ Undiff*Falling*Hispanic } & -.0004578 & -.000201 & .0124042 & -.0096565 & .0053293 & -.0053183 \\
\hline & 49) & 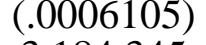 & & & & 762) \\
\hline $\begin{array}{l}\mathrm{N} \\
R^{2}\end{array}$ & $\begin{array}{l}3,184,345 \\
00099\end{array}$ & $\begin{array}{l}3,184,345 \\
00056\end{array}$ & $\begin{array}{l}152,433 \\
0047\end{array}$ & 152,433 & $322,6 / 1$ & $322,6 / 1$ \\
\hline
\end{tabular}

Notes: Reported coefficients are changes in parameters from 2008-2012 relative to the entire sample. The sample is males ages 25-55. All estimates employ CPS sample weights. Standard errors adjust for clustering. All specifications also included a constant, age, age squared, marital status, education, occupation and industry, and state and month fixed effects. ${ }^{*} \mathrm{p}<0.1 ;{ }^{* *} \mathrm{p}<0.05 ; * * * \mathrm{p}<0.01$ 
for observations that are after the start of the Great Recession. Changes in estimated transitions are reported in Table 12.

Similar to the tests in the two state model, there is a decrease in the unemployment-toemployment transition rate for blacks of about 2.1 percentage points from the pre-Great Recession period to afterwards, as shown in column 3 of Panel A. For both blacks and Hispanics, there is also a decrease in the base probability of moving from unemployment to not in the labor force in the post-Great Recession period. For each percentage point increase in the unemployment rate, black men are 0.08 of a percentage point less likely to move from employment to unemployment, and are 0.37 of a percentage point more likely to move from nonparticipation to employment in the post-Great Recession period than in the pre-Great Recession period. This pattern is generally consistent with findings from the two-state model in Table 11 where the cyclical responsiveness of the probability of moving into unemployment was attenuated although the base probability of becoming unemployed increased.

\section{Conclusion}

Using matched monthly observations from the Current Population Survey from 1996 to 2012, this paper examines labor market transitions most closely associated with the assertion that minorities are last hired during periods of strong economic growth and first fired during recessions focusing on the experiences of both blacks and Hispanics. The analysis also decomposes the sample into periods prior to and after the initiation of the Great Recession and provides tests of changes in patterns of labor market transitions across periods.

The analysis initially examines probabilities of transitioning between employment and unemployment over the entire sample (1996-2012), providing evidence that both blacks and Hispanics have a higher probability of being unemployed in the following month than whites and that this probability increases as business conditions worsen. This pattern among minorities (blacks and Hispanics) is consistent with the hypothesis that minorities are the first fired when the economy weakens. For the period of 2008-2012, blacks do not behave differently than whites in their responsiveness to economic downturns in terms of their unemployment entry rate; however, it is important that their rate of entry into unemployment along with that of Hispanics structurally increased during the Great Recession.

For transitions from unemployment to being employed, considerable evidence shows that 
transition rates for Hispanics during weak business cycle conditions rise more rapidly than for whites over the entire sample period of 1996-2012 and for blacks in the sample period from 20082012. In these periods, the evidence would support the conclusion that minorities are first hired.

While only considering the transitions between employment and unemployment, the most important finding in comparing the period after the initiation of the Great Recession to the overall sample period is the size of the estimated decrease in the probability of being re-employed from one month to the next for blacks. Estimates indicate that the chance of re-employment declined by about 2 percentage points while remaining structurally unchanged for other groups. Thus, black unemployment rates would be expected to rise above those of other groups due to this reduction in the odds of becoming re-employed.

The analysis is then further expanded to include transitions across all three labor force states. Adding transitions into and out of the labor force, the first fired pattern is reinforced for blacks and Hispanics over the entire sample period of 1996-2012, for both groups in the 1996-2007 period, and for Hispanics from 2008-2012. Thus, these results support and strengthen conclusions that might be drawn from the two-way transition model. The pattern of being first hired is supported for blacks and Hispanics over the entire sample period but are not as clear in either sub-period. There is little evidence that minorities are last hired.

In considering three possible labor market transitions, the finding from the two-state transition model is confirmed: one of the most important changes that occurred in labor market dynamics in the Great Recession was a sizeable decrease in the base probability of moving from being unemployed to employed among blacks. The probability of making this transition, independent of business cycle conditions decreased by more than 2 percentage points while controlling for a range of possible confounders. This particularly striking and consistent result across estimates suggests that the sharp decline in demand associated with the Great Recession overwhelmed normal processes of labor market dynamics, with blacks bearing the largest brunt of this impact through a reduced probability of being rehired. 


\section{References}

Allegretto, S., \& Lynch, D. (2010). The Composition of the Unemployed and the Long-term Unemployed in Tough Labor Markets. Monthly Labor Review, 133(10), 3-18.

Abowd, J. M., \& Killingsworth, M. R. (1984). Do minority/white unemployment differences really exist? Journal of Business \& Economic Statistics, 2(1), 64-72.

Abraham, K. G., \& Shimer, R. (2001). Changes in unemployment duration and labor force attachment (No. w8513). National Bureau of Economic Research.

Badgett, M. L. (1994). Rising black unemployment: Changes in job stability or in employability? The Review of Black Political Economy, 22(3), 55-75.

Blanchard, O. J., Diamond, P., Hall, R. E., \& Murphy, K. (1990). The cyclical behavior of the gross flows of US workers. Brookings Papers on Economic Activity, 1990(2), 85-155.

Borjas, G. J., \& Tienda, M. (Eds.). (1985). Hispanics in the US Economy. Orlando: Academic Press.

Bound, J., \& Freeman, R. B. (1992). What went wrong? The erosion of relative earnings and employment among young black men in the 1980s. The Quarterly Journal of Economics, 107(1), 201-232.

Bradbury, K. L. (2000). Rising tide in the labor market: to what degree do expansions benefit the disadvantaged? New England Economic Review, 3-34.

Cattan, P. (1988). Growing Presence of Hispanics in the US Work Force. The Monthly Labor Review, 111, 9.

Clark, K. B., \& Summers, L. H. (1981). Demographic Differences in Cyclical Employment Variation. Journal of Human Resources, 61-79.

Constant, A. F., \& Zimmermann, K. F. (2014). Self-employment against employment or unemployment: Markov transitions across the business cycle. Eurasian Business Review, 4(1), 51-87.

Couch, K. A., \& Fairlie, R. (2010). Last hired, first fired? Black-white unemployment and the business cycle. Demography, 47(1), 227-247.

De La Rica, S., \& Rebello-Sanz, Y. (2015). Gender Differentials in Unemployment Ins and Outs During the Great Recession in Spain. IZA Discussion Paper No. 9135.

DeFreitas, G. (1986). A time-series analysis of Hispanic unemployment. Journal of Human Resources, 24-43.

Fairlie, R. W. (2013). Entrepreneurship, Economic Conditions, and the Great Recession. Journal of Economics and Management Strategy, 22(2): 207-231.

Fairlie, R. W., \& Sundstrom, W. A. (1997). The racial unemployment gap in long-run perspective. The American Economic Review, 87(2), 306-310.

Fairlie, R. W., \& Sundstrom, W. A. (1998). Emergence, Persistence, and Recent Widening of the Racial Unemployment Gap, Industrial \& Labor Relations Review, 52, 252.

Freeman, R. B., Gordon, R. A., Bell, D., \& Hall, R. E. (1973). Changes in the labor market for black Americans, 1948-72. Brookings Papers on Economic Activity, 1973(1), 67-131.

Freeman, R. B., \& Rodgers III, W. M. (1999). Area economic conditions and the labor market outcomes of young men in the 1990s expansion (No. w7073). National Bureau of Economic Research.

Holzer, H. J., \& Offner, P. (2006). Trends in the employment outcomes of young Black men, 1979-2000. Black males left behind, 11-38.

Hoynes, H. (1999). The employment, earnings, and income of less skilled workers over the business cycle (No. w7188). National Bureau of Economic Research. 
Hoynes, H. W., Miller, D. L., \& Schaller, J. (2012). Who suffers during recessions? (No. w17951). National Bureau of Economic Research.

Madrian, B. C., \& Lefgren, L. J. (2000). An approach to longitudinally matching Current Population Survey (CPS) respondents. Journal of Economic and Social Measurement, 26(1), 31-62.

Orrenius, P. M., \& Zavodny, M. (2009). Tied to the business cycle: how immigrants fare in good and bad economic times. Migration Policy Institute. 
Table A.1 Descriptive Statistics of Two-way Transitions, Sample Period: 1996-2012

\begin{tabular}{|c|c|c|c|c|}
\hline & \multicolumn{2}{|c|}{$\begin{array}{c}\text { Employment-to- } \\
\text { Unemployment } \\
\text { Transition } \\
(\mathrm{N}=3,150,683)\end{array}$} & \multicolumn{2}{|c|}{$\begin{array}{l}\text { Unemployment-to- } \\
\text { Employment } \\
\text { Transition } \\
(\mathrm{N}=131,761)\end{array}$} \\
\hline & Mean & S.D. & Mean & S.D. \\
\hline \multicolumn{5}{|l|}{ Outcome Variables } \\
\hline $\begin{array}{l}\text { Employment-to-Unemployment Probability } \\
\text { Unemployment-to-Employment Probability }\end{array}$ & 0.01 & 0.11 & 0.31 & 0.46 \\
\hline \multicolumn{5}{|l|}{ Explanatory Variables } \\
\hline $\begin{array}{l}\text { Black } \\
(1=\text { Black })\end{array}$ & 0.08 & 0.27 & 0.15 & 0.36 \\
\hline $\begin{array}{l}\text { Hispanic } \\
\text { (1=Hispanic) }\end{array}$ & 0.11 & 0.32 & 0.16 & 0.36 \\
\hline Undiff & 0.37 & 2.03 & 1.41 & 2.43 \\
\hline Age & 40.39 & 8.60 & 39.26 & 8.89 \\
\hline Age Squared & 1704.97 & 692.79 & 1620.64 & 706.56 \\
\hline $\begin{array}{l}\text { Marital Status } \\
\text { (1=Married) }\end{array}$ & 0.69 & 0.46 & 0.48 & 0.50 \\
\hline $\begin{array}{l}\text { Education } 1 \\
\text { (1=Less than High School) }\end{array}$ & 0.09 & 0.29 & 0.19 & 0.39 \\
\hline $\begin{array}{l}\text { Education } 2 \\
\text { (1=High School) }\end{array}$ & 0.32 & 0.46 & 0.40 & 0.49 \\
\hline $\begin{array}{l}\text { Education } 3 \\
\text { (1=Some College No Degree) }\end{array}$ & 0.23 & 0.42 & 0.22 & 0.41 \\
\hline $\begin{array}{l}\text { Education } 4 \\
\text { (1=College and Above) }\end{array}$ & 0.36 & 0.48 & 0.20 & 0.40 \\
\hline $\begin{array}{l}\text { Type of Worker } 1 \\
\text { (1=Government) }\end{array}$ & 0.13 & 0.34 & 0.05 & 0.22 \\
\hline $\begin{array}{l}\text { Type of Worker } 2 \\
\text { (1=Private) }\end{array}$ & 0.73 & 0.44 & 0.89 & 0.32 \\
\hline $\begin{array}{l}\text { Type of Worker } 3 \\
\text { (1=Self-employed) }\end{array}$ & 0.14 & 0.35 & 0.06 & 0.24 \\
\hline $\begin{array}{l}\text { Industry } 1 \\
\text { (1=Agriculture) }\end{array}$ & 0.03 & 0.16 & 0.02 & 0.16 \\
\hline $\begin{array}{l}\text { Industry } 2 \\
\text { (1=Mining) }\end{array}$ & 0.01 & 0.11 & 0.01 & 0.11 \\
\hline $\begin{array}{l}\text { Industry } 3 \\
\text { (1=Construction) }\end{array}$ & 0.13 & 0.34 & 0.26 & 0.44 \\
\hline $\begin{array}{l}\text { Industry } 4 \\
\text { (1=Manufacturing) }\end{array}$ & 0.17 & 0.38 & 0.17 & 0.37 \\
\hline $\begin{array}{l}\text { Industry } 5 \\
\text { (1=Wholesale \& Retail) }\end{array}$ & 0.14 & 0.35 & 0.12 & 0.32 \\
\hline $\begin{array}{l}\text { Industry } 6 \\
\text { (1=Transportation \& Utilities) }\end{array}$ & 0.08 & 0.27 & 0.06 & 0.24 \\
\hline $\begin{array}{l}\text { Industry } 7 \\
\text { (1=Information) }\end{array}$ & 0.03 & 0.16 & 0.03 & 0.16 \\
\hline $\begin{array}{l}\text { Industry } 8 \\
\text { (1=Financial Activities) }\end{array}$ & 0.06 & 0.23 & 0.04 & 0.19 \\
\hline Industry 9 & 0.11 & 0.31 & 0.12 & 0.33 \\
\hline
\end{tabular}


(1=Professional and Business Services)

\section{Industry 10}

(1=Educational and Health Services)

Industry 11

(1=Leisure and Hospitality)

Industry 12

(1=Other Services)

Industry 13

(1=Public Administration)

$\begin{array}{llll}0.10 & 0.30 & 0.05 & 0.21 \\ 0.05 & 0.22 & 0.07 & 0.26 \\ 0.04 & 0.20 & 0.04 & 0.19 \\ 0.06 & 0.23 & 0.02 & 0.13\end{array}$

Notes: Undiff = the state-level unemployment rate - the national natural rate of unemployment. 
Table A.2 Descriptive Statistics of Two-way Transitions, Sample Period: 1996-2007

\begin{tabular}{|c|c|c|c|c|}
\hline & \multicolumn{2}{|c|}{$\begin{array}{c}\text { Employment-to- } \\
\text { Unemployment } \\
\text { Transition } \\
(\mathrm{N}=2,287,455) \\
\end{array}$} & \multicolumn{2}{|c|}{$\begin{array}{l}\text { Unemployment-to- } \\
\text { Employment Transition } \\
(\mathrm{N}=74,251)\end{array}$} \\
\hline & Mean & S.D. & Mean & S.D. \\
\hline \multicolumn{5}{|l|}{ Outcome Variables } \\
\hline $\begin{array}{l}\text { Employment-to-Unemployment Probability } \\
\text { Unemployment-to-Employment Probability }\end{array}$ & 0.01 & 0.10 & 0.36 & 0.48 \\
\hline \multicolumn{5}{|l|}{ Explanatory Variables } \\
\hline $\begin{array}{l}\text { Black } \\
(1=\text { Black })\end{array}$ & 0.08 & 0.26 & 0.15 & 0.36 \\
\hline $\begin{array}{l}\text { Hispanic } \\
\text { (1=Hispanic) }\end{array}$ & 0.11 & 0.31 & 0.14 & 0.35 \\
\hline Undiff & -0.45 & 1.12 & -0.13 & 1.12 \\
\hline Age & 40.25 & 8.50 & 38.98 & 8.70 \\
\hline Age Squared & 1692.50 & 683.98 & 1595.25 & 689.06 \\
\hline $\begin{array}{l}\text { Marital Status } \\
\text { (1=Married) }\end{array}$ & 0.70 & 0.46 & 0.49 & 0.50 \\
\hline $\begin{array}{l}\text { Education } 1 \\
\text { (1=Less than High School) }\end{array}$ & 0.10 & 0.29 & 0.19 & 0.39 \\
\hline $\begin{array}{l}\text { Education } 2 \\
\text { (1=High School) }\end{array}$ & 0.32 & 0.47 & 0.39 & 0.49 \\
\hline $\begin{array}{l}\text { Education } 3 \\
\text { (1=Some College No Degree) }\end{array}$ & 0.23 & 0.42 & 0.22 & 0.41 \\
\hline $\begin{array}{l}\text { Education } 4 \\
\text { (1=College and Above) }\end{array}$ & 0.35 & 0.48 & 0.20 & 0.40 \\
\hline $\begin{array}{l}\text { Type of Worker } 1 \\
\text { (1=Government) }\end{array}$ & 0.13 & 0.34 & 0.05 & 0.23 \\
\hline $\begin{array}{l}\text { Type of Worker } 2 \\
\text { (1=Private) }\end{array}$ & 0.73 & 0.45 & 0.89 & 0.32 \\
\hline $\begin{array}{l}\text { Type of Worker } 3 \\
\text { (1=Self-employed) }\end{array}$ & 0.14 & 0.35 & 0.06 & 0.23 \\
\hline $\begin{array}{l}\text { Industry } 1 \\
\text { (1=Agriculture) }\end{array}$ & 0.03 & 0.16 & 0.03 & 0.16 \\
\hline $\begin{array}{l}\text { Industry } 2 \\
\text { (1=Mining) }\end{array}$ & 0.01 & 0.11 & 0.01 & 0.11 \\
\hline $\begin{array}{l}\text { Industry } 3 \\
(1=\text { Construction })\end{array}$ & 0.13 & 0.34 & 0.24 & 0.43 \\
\hline $\begin{array}{l}\text { Industry } 4 \\
\text { (1=Manufacturing) }\end{array}$ & 0.18 & 0.39 & 0.18 & 0.38 \\
\hline $\begin{array}{l}\text { Industry } 5 \\
\text { (1=Wholesale \& Retail) }\end{array}$ & 0.14 & 0.35 & 0.12 & 0.33 \\
\hline $\begin{array}{l}\text { Industry } 6 \\
\text { (1=Transportation \& Utilities) }\end{array}$ & 0.08 & 0.27 & 0.06 & 0.24 \\
\hline $\begin{array}{l}\text { Industry } 7 \\
\text { (1=Information) }\end{array}$ & 0.03 & 0.16 & 0.03 & 0.16 \\
\hline $\begin{array}{l}\text { Industry } 8 \\
\text { (1=Financial Activities) }\end{array}$ & 0.06 & 0.23 & 0.04 & 0.18 \\
\hline Industry 9 & 0.10 & 0.30 & 0.12 & 0.33 \\
\hline
\end{tabular}


(1=Professional and Business Services)

\section{Industry 10}

(1=Educational and Health Services)

Industry 11

(1=Leisure and Hospitality)

Industry 12

(1=Other Services)

Industry 13

(1=Public Administration)

$\begin{array}{llll}0.10 & 0.29 & 0.05 & 0.21 \\ 0.05 & 0.22 & 0.07 & 0.25 \\ 0.04 & 0.20 & 0.04 & 0.19 \\ 0.05 & 0.23 & 0.02 & 0.13\end{array}$

Notes: Undiff = the state-level unemployment rate - the national natural rate of unemployment. 
Table A.3 Descriptive Statistics of Two-way Transitions, Sample Period: 2008-2012

\begin{tabular}{|c|c|c|c|c|}
\hline & \multicolumn{2}{|c|}{$\begin{array}{c}\text { Employment-to- } \\
\text { Unemployment } \\
\text { Transition }(\mathrm{N}=863,228)\end{array}$} & \multicolumn{2}{|c|}{$\begin{array}{c}\text { Unemployment-to- } \\
\text { Employment Transition } \\
(\mathrm{N}=57,510)\end{array}$} \\
\hline & Mean & S.D. & Mean & S.D. \\
\hline \multicolumn{5}{|l|}{ Outcome Variables } \\
\hline $\begin{array}{l}\text { Employment-to-Unemployment Probability } \\
\text { Unemployment-to-Employment Probability }\end{array}$ & 0.02 & 0.12 & 0.24 & 0.43 \\
\hline \multicolumn{5}{|l|}{ Explanatory Variables } \\
\hline $\begin{array}{l}\text { Black } \\
(1=\text { Black })\end{array}$ & 0.08 & 0.27 & 0.15 & 0.36 \\
\hline $\begin{array}{l}\text { Hispanic } \\
\text { (1=Hispanic) }\end{array}$ & 0.13 & 0.34 & 0.18 & 0.38 \\
\hline Undiff & 2.55 & 2.28 & 3.40 & 2.21 \\
\hline Age & 40.74 & 8.84 & 39.63 & 9.12 \\
\hline Age Squared & 1738.00 & 714.56 & 1653.41 & 727.22 \\
\hline $\begin{array}{l}\text { Marital Status } \\
\text { (1=Married) }\end{array}$ & 0.66 & 0.47 & 0.47 & 0.50 \\
\hline $\begin{array}{l}\text { Education } 1 \\
\text { (1=Less than High School) }\end{array}$ & 0.09 & 0.28 & 0.18 & 0.38 \\
\hline $\begin{array}{l}\text { Education } 2 \\
\text { (1=High School) }\end{array}$ & 0.31 & 0.46 & 0.40 & 0.49 \\
\hline $\begin{array}{l}\text { Education } 3 \\
\text { (1=Some College No Degree) }\end{array}$ & 0.22 & 0.42 & 0.22 & 0.42 \\
\hline $\begin{array}{l}\text { Education } 4 \\
\text { (1=College and Above) }\end{array}$ & 0.38 & 0.49 & 0.20 & 0.40 \\
\hline $\begin{array}{l}\text { Type of Worker } 1 \\
\text { (1=Government) }\end{array}$ & 0.13 & 0.34 & 0.05 & 0.21 \\
\hline $\begin{array}{l}\text { Type of Worker } 2 \\
\text { (1=Private) }\end{array}$ & 0.74 & 0.44 & 0.89 & 0.32 \\
\hline $\begin{array}{l}\text { Type of Worker } 3 \\
\text { (1=Self-employed) }\end{array}$ & 0.13 & 0.34 & 0.06 & 0.25 \\
\hline $\begin{array}{l}\text { Industry } 1 \\
\text { (1=Agriculture) }\end{array}$ & 0.02 & 0.15 & 0.02 & 0.15 \\
\hline $\begin{array}{l}\text { Industry } 2 \\
\text { (1=Mining) }\end{array}$ & 0.01 & 0.12 & 0.01 & 0.11 \\
\hline $\begin{array}{l}\text { Industry } 3 \\
\text { (1=Construction) }\end{array}$ & 0.13 & 0.34 & 0.28 & 0.45 \\
\hline $\begin{array}{l}\text { Industry } 4 \\
\text { (1=Manufacturing) }\end{array}$ & 0.15 & 0.36 & 0.15 & 0.36 \\
\hline $\begin{array}{l}\text { Industry } 5 \\
\text { (1=Wholesale \& Retail) }\end{array}$ & 0.13 & 0.34 & 0.12 & 0.32 \\
\hline $\begin{array}{l}\text { Industry } 6 \\
\text { (1=Transportation \& Utilities) }\end{array}$ & 0.08 & 0.27 & 0.06 & 0.23 \\
\hline $\begin{array}{l}\text { Industry } 7 \\
\text { (1=Information) }\end{array}$ & 0.03 & 0.16 & 0.02 & 0.15 \\
\hline $\begin{array}{l}\text { Industry } 8 \\
\text { (1=Financial Activities) }\end{array}$ & 0.06 & 0.24 & 0.04 & 0.20 \\
\hline $\begin{array}{l}\text { Industry } 9 \\
\text { (1=Professional and Business Services) }\end{array}$ & 0.12 & 0.32 & 0.12 & 0.33 \\
\hline
\end{tabular}




\begin{tabular}{lllll} 
Industry 10 & & & 0.05 & 0.21 \\
$\begin{array}{l}\text { Industry 11 } \\
\text { Inde-Leisure and Hospitality) }\end{array}$ & 0.10 & 0.30 & & 0.26 \\
$\begin{array}{l}\text { Industry 12 } \\
\text { (1=Other Services) }\end{array}$ & 0.06 & 0.24 & 0.07 & 0.19 \\
$\begin{array}{l}\text { Industry 13 } \\
\text { (1=Public Administration) }\end{array}$ & 0.04 & 0.20 & 0.04 & 0.12 \\
\hline
\end{tabular}

Notes: Undiff $=$ the state-level unemployment rate - the national natural rate of unemployment. 
Table A.4 Descriptive Statistics of Three-way Transitions, Sample Period: 1996-2012

\begin{tabular}{|c|c|c|c|c|c|c|}
\hline & \multicolumn{2}{|c|}{$\begin{array}{c}\text { Employment-to- } \\
\text { Unemployment \& } \\
\text { Employment-to- } \\
\text { Nonparticipation } \\
\text { Transitions } \\
(\mathrm{N}=3,184,345) \\
\end{array}$} & \multicolumn{2}{|c|}{$\begin{array}{l}\text { Unemployment-to } \\
\text { Employment \& } \\
\text { Unemployment-to- } \\
\text { Nonparticipation } \\
\text { Transitions } \\
(\mathrm{N}=152,433)\end{array}$} & \multicolumn{2}{|c|}{$\begin{array}{l}\text { Nonparticipation-to- } \\
\text { Employment \& } \\
\text { Nonparticipation-to- } \\
\text { Unemployment } \\
\text { Transitions } \\
(\mathrm{N}=322,671)\end{array}$} \\
\hline & Mean & S.D. & Mean & S.D. & Mean & S.D. \\
\hline \multicolumn{7}{|l|}{ Outcome Variables } \\
\hline $\begin{array}{l}\text { Employment-to-Unemployment } \\
\text { Probability }\end{array}$ & 0.01 & 0.11 & & & & \\
\hline $\begin{array}{l}\text { Employment-to-Nonparticipation } \\
\text { Probability }\end{array}$ & 0.01 & 0.10 & & & & \\
\hline $\begin{array}{l}\text { Unemployment-to-Employment } \\
\text { Probability }\end{array}$ & & & 0.27 & 0.44 & & \\
\hline $\begin{array}{l}\text { Unemployment-to-Nonparticipation } \\
\text { Probability }\end{array}$ & & & 0.14 & 0.34 & & \\
\hline $\begin{array}{l}\text { Nonparticipation-to-Employment } \\
\text { Probability }\end{array}$ & & & & & 0.09 & 0.28 \\
\hline $\begin{array}{l}\text { Nonparticipation-to-Unemployment } \\
\text { Probability }\end{array}$ & & & & & 0.06 & 0.23 \\
\hline \multicolumn{7}{|l|}{ Explanatory Variables } \\
\hline $\begin{array}{l}\text { Black } \\
\text { (1=Black) }\end{array}$ & 0.08 & 0.27 & 0.16 & 0.37 & 0.17 & 0.38 \\
\hline $\begin{array}{l}\text { Hispanic } \\
\text { (1=Hispanic) }\end{array}$ & 0.11 & 0.32 & 0.15 & 0.36 & 0.11 & 0.31 \\
\hline Undiff & 0.38 & 2.03 & 1.39 & 2.42 & 0.74 & 2.15 \\
\hline Age & 40.38 & 8.61 & 39.23 & 8.92 & 42.59 & 9.15 \\
\hline Age Squared & 1704.58 & 693.34 & 1618.72 & 708.72 & 1897.38 & 748.79 \\
\hline $\begin{array}{l}\text { Marital Status } \\
\text { (1=Married) }\end{array}$ & 0.68 & 0.47 & 0.47 & 0.50 & 0.43 & 0.49 \\
\hline $\begin{array}{l}\text { Education } 1 \\
\text { (1=Less than High School) }\end{array}$ & 0.09 & 0.29 & 0.19 & 0.39 & 0.24 & 0.43 \\
\hline $\begin{array}{l}\text { Education } 2 \\
\text { (1=High School) }\end{array}$ & 0.32 & 0.47 & 0.40 & 0.49 & 0.38 & 0.49 \\
\hline $\begin{array}{l}\text { Education } 3 \\
\text { (1=Some College No Degree) }\end{array}$ & 0.23 & 0.42 & 0.22 & 0.41 & 0.21 & 0.41 \\
\hline $\begin{array}{l}\text { Education } 4 \\
\text { (1=College and Above) }\end{array}$ & 0.36 & 0.48 & 0.19 & 0.40 & 0.17 & 0.38 \\
\hline $\begin{array}{l}\text { Type of Worker } 1 \\
\text { (1=Government) }\end{array}$ & 0.13 & 0.34 & 0.05 & 0.22 & & \\
\hline $\begin{array}{l}\text { Type of Worker } 2 \\
\text { (1=Private) }\end{array}$ & 0.73 & 0.44 & 0.88 & 0.32 & & \\
\hline $\begin{array}{l}\text { Type of Worker } 3 \\
\text { (1=Self-employed) }\end{array}$ & 0.14 & 0.35 & 0.06 & 0.24 & & \\
\hline $\begin{array}{l}\text { Industry } 1 \\
\text { (1=Agriculture) }\end{array}$ & 0.03 & 0.16 & 0.02 & 0.16 & & \\
\hline $\begin{array}{l}\text { Industry } 2 \\
\text { (1=Mining) }\end{array}$ & 0.01 & 0.11 & 0.01 & 0.11 & & \\
\hline $\begin{array}{l}\text { Industry } 3 \\
\text { (1=Construction) }\end{array}$ & 0.13 & 0.34 & 0.25 & 0.43 & & \\
\hline $\begin{array}{l}\text { Industry } 4 \\
\text { (1=Manufacturing) }\end{array}$ & 0.17 & 0.38 & 0.16 & 0.37 & & \\
\hline Industry 5 & 0.14 & 0.35 & 0.12 & 0.33 & & \\
\hline
\end{tabular}


(1=Wholesale \& Retail)

$\begin{array}{llccc}\begin{array}{l}\text { Industry 6 } \\ \text { (1=Transportation \& Utilities) }\end{array} & 0.08 & 0.27 & 0.06 & 0.24 \\ \begin{array}{l}\text { Industry 7 } \\ \text { (1=Information) }\end{array} & 0.03 & 0.16 & 0.02 & 0.16 \\ \begin{array}{l}\text { Industry 8 } \\ \text { (1=Financial Activities) }\end{array} & 0.06 & 0.23 & 0.04 & 0.19 \\ \begin{array}{l}\text { Industry 9 } \\ \text { (1=Professional and Business Services) }\end{array} & 0.11 & 0.31 & 0.12 & 0.33 \\ \begin{array}{l}\text { Industry 10 } \\ \text { (1=Educational and Health Services) }\end{array} & 0.10 & 0.30 & 0.05 & 0.21 \\ \begin{array}{l}\text { Industry 11 } \\ \text { (1=Leisure and Hospitality) }\end{array} & 0.05 & 0.22 & 0.07 & 0.26 \\ \begin{array}{l}\text { Industry 12 } \\ \text { (1=Other Services) }\end{array} & 0.04 & 0.20 & 0.04 & 0.19 \\ \begin{array}{l}\text { Industry 13 } \\ \text { (1=Public Administration) }\end{array} & 0.06 & 0.23 & 0.02 & 0.13\end{array}$

Notes: The industry and occupation variables are not present in the samples which contain the Nonparticipation-to-Employment and the Nonparticipation-to-Unemployment transitions because these groups contain individuals whose labor force states start as not in the labor force. The industry and occupation code are only observed for people who are in the labor force, i.e. samples that contain the Employment-to-Unemployment, the Employment-to-Nonparticipation, the Unemployment-to-Employment, and the Unemployment-toNonparticipation transitions.

$\dagger$ Undiff $=$ the state-level unemployment rate - the national natural rate of unemployment. 


\begin{tabular}{|c|c|c|c|c|c|c|}
\hline & \multicolumn{2}{|c|}{$\begin{array}{c}\text { Employment-to- } \\
\text { Unemployment \& } \\
\text { Employment-to- } \\
\text { Nonparticipation } \\
\text { Transitions } \\
(\mathrm{N}=2,311,516) \\
\end{array}$} & \multicolumn{2}{|c|}{$\begin{array}{l}\text { Unemployment-to } \\
\text { Employment \& } \\
\text { Unemployment-to- } \\
\text { Nonparticipation } \\
\text { Transitions } \\
(\mathrm{N}=86,434)\end{array}$} & \multicolumn{2}{|c|}{$\begin{array}{l}\text { Nonparticipation-to- } \\
\text { Employment \& } \\
\text { Nonparticipation-to- } \\
\text { Unemployment } \\
\text { Transitions } \\
(217,833)\end{array}$} \\
\hline & Mean & S.D. & Mean & S.D. & Mean & S.D. \\
\hline \multicolumn{7}{|l|}{ Outcome Variables } \\
\hline $\begin{array}{l}\text { Employment-to-Unemployment } \\
\text { Probability }\end{array}$ & 0.01 & 0.10 & & & & \\
\hline $\begin{array}{l}\text { Employment-to-Nonparticipation } \\
\text { Probability }\end{array}$ & 0.01 & 0.10 & & & & \\
\hline $\begin{array}{l}\text { Unemployment-to-Employment } \\
\text { Probability }\end{array}$ & & & 0.31 & 0.46 & & \\
\hline $\begin{array}{l}\text { Unemployment-to-Nonparticipation } \\
\text { Probability }\end{array}$ & & & 0.14 & 0.35 & & \\
\hline $\begin{array}{l}\text { Nonparticipation-to-Employment } \\
\text { Probability }\end{array}$ & & & & & 0.09 & 0.29 \\
\hline $\begin{array}{l}\text { Nonparticipation-to-Unemployment } \\
\text { Probability }\end{array}$ & & & & & 0.05 & 0.22 \\
\hline \multicolumn{7}{|l|}{ Explanatory Variables } \\
\hline $\begin{array}{l}\text { Black } \\
\text { (1=Black) }\end{array}$ & 0.08 & 0.27 & 0.16 & 0.37 & 0.17 & 0.38 \\
\hline $\begin{array}{l}\text { Hispanic } \\
\text { (1=Hispanic) }\end{array}$ & 0.11 & 0.31 & 0.14 & 0.35 & 0.10 & 0.30 \\
\hline Undiff & -0.45 & 1.12 & -0.13 & 1.12 & -0.29 & 1.11 \\
\hline Age & 40.25 & 8.51 & 38.97 & 8.74 & 42.64 & 9.00 \\
\hline Age Squared & 1692.19 & 684.53 & 1595.04 & 691.74 & 1899.28 & 738.61 \\
\hline $\begin{array}{l}\text { Marital Status } \\
\text { (1=Married) }\end{array}$ & 0.69 & 0.46 & 0.48 & 0.50 & 0.44 & 0.50 \\
\hline $\begin{array}{l}\text { Education } 1 \\
\text { (1=Less than High School) }\end{array}$ & 0.10 & 0.30 & 0.20 & 0.40 & 0.25 & 0.43 \\
\hline $\begin{array}{l}\text { Education } 2 \\
\text { (1=High School) }\end{array}$ & 0.32 & 0.47 & 0.39 & 0.49 & 0.37 & 0.48 \\
\hline $\begin{array}{l}\text { Education } 3 \\
\text { (1=Some College No Degree) }\end{array}$ & 0.23 & 0.42 & 0.22 & 0.41 & 0.21 & 0.41 \\
\hline $\begin{array}{l}\text { Education } 4 \\
\text { (1=College and Above) }\end{array}$ & 0.35 & 0.48 & 0.20 & 0.40 & 0.17 & 0.37 \\
\hline $\begin{array}{l}\text { Type of Worker } 1 \\
\text { (1=Government) }\end{array}$ & 0.13 & 0.34 & 0.06 & 0.23 & & \\
\hline $\begin{array}{l}\text { Type of Worker } 2 \\
\text { (1=Private) }\end{array}$ & 0.73 & 0.45 & 0.88 & 0.32 & & \\
\hline $\begin{array}{l}\text { Type of Worker } 3 \\
\text { (1=Self-employed) }\end{array}$ & 0.14 & 0.35 & 0.06 & 0.24 & & \\
\hline $\begin{array}{l}\text { Industry } 1 \\
\text { (1=Agriculture) }\end{array}$ & 0.03 & 0.16 & 0.03 & 0.16 & & \\
\hline $\begin{array}{l}\text { Industry } 2 \\
\text { (1=Mining) }\end{array}$ & 0.01 & 0.10 & 0.01 & 0.11 & & \\
\hline $\begin{array}{l}\text { Industry } 3 \\
\text { (1=Construction) }\end{array}$ & 0.13 & 0.34 & 0.23 & 0.42 & & \\
\hline $\begin{array}{l}\text { Industry } 4 \\
\text { (1=Manufacturing) }\end{array}$ & 0.18 & 0.39 & 0.17 & 0.38 & & \\
\hline Industry 5 & 0.14 & 0.35 & 0.12 & 0.33 & & \\
\hline
\end{tabular}


(1=Wholesale \& Retail)

$\begin{array}{llccc}\begin{array}{l}\text { Industry 6 } \\ \text { (1=Transportation \& Utilities) }\end{array} & 0.08 & 0.27 & 0.06 & 0.24 \\ \begin{array}{l}\text { Industry 7 } \\ \text { (1=Information) }\end{array} & 0.03 & 0.16 & 0.03 & 0.16 \\ \begin{array}{l}\text { Industry 8 } \\ \text { (1=Financial Activities) }\end{array} & 0.06 & 0.23 & 0.03 & 0.18 \\ \begin{array}{l}\text { Industry 9 } \\ \text { (1=Professional and Business Services) }\end{array} & 0.10 & 0.31 & 0.12 & 0.33 \\ \begin{array}{l}\text { Industry 10 } \\ \text { (1=Educational and Health Services) }\end{array} & 0.09 & 0.29 & 0.05 & 0.21 \\ \begin{array}{l}\text { Industry 11 } \\ \text { (1=Leisure and Hospitality) }\end{array} & 0.05 & 0.22 & 0.07 & 0.26 \\ \begin{array}{l}\text { Industry 12 } \\ \text { (1=Other Services) }\end{array} & 0.04 & 0.20 & 0.04 & 0.20 \\ \begin{array}{l}\text { Industry 13 } \\ \text { (1=Public Administration) }\end{array} & 0.05 & 0.23 & 0.02 & 0.13\end{array}$

Notes: The industry and occupation variables are not present in the samples which contain the Nonparticipation-to-Employment and the Nonparticipation-to-Unemployment transitions because these groups contain individuals whose labor force states start as not in the labor force. The industry and occupation code are only observed for people who are in the labor force, i.e. samples that contain the Employment-to-Unemployment, the Employment-to-Nonparticipation, the Unemployment-to-Employment, and the Unemployment-toNonparticipation transitions.

$\dagger$ Undiff $=$ the state-level unemployment rate - the national natural rate of unemployment. 
Table A.6 Descriptive Statistics of Three-way Transitions, Sample Period: 2008-2012

\begin{tabular}{|c|c|c|c|c|c|c|}
\hline & \multicolumn{2}{|c|}{$\begin{array}{c}\text { Employment-to- } \\
\text { Unemployment \& } \\
\text { Employment-to- } \\
\text { Nonparticipation } \\
\text { Transitions } \\
(\mathrm{N}=872,829)\end{array}$} & \multicolumn{2}{|c|}{$\begin{array}{c}\text { Unemployment-to } \\
\text { Employment \& } \\
\text { Unemployment- } \\
\text { to- } \\
\text { Nonparticipation } \\
\text { Transitions } \\
\text { (N=65,999) }\end{array}$} & \multicolumn{2}{|c|}{$\begin{array}{l}\text { Nonparticipation- } \\
\text { to-Employment \& } \\
\text { Nonparticipation- } \\
\text { to-Unemployment } \\
\text { Transitions } \\
\quad(\mathrm{N}=104,838)\end{array}$} \\
\hline & Mean & S.D. & Mean & S.D. & Mean & S.D. \\
\hline \multicolumn{7}{|l|}{ Outcome Variables } \\
\hline $\begin{array}{l}\text { Employment-to- } \\
\text { Unemployment Probability }\end{array}$ & 0.02 & 0.12 & & & & \\
\hline $\begin{array}{l}\text { Employment-to- } \\
\text { Nonparticipation Probability }\end{array}$ & 0.01 & 0.10 & & & & \\
\hline $\begin{array}{l}\text { Unemployment-to- } \\
\text { Employment Probability }\end{array}$ & & & 0.21 & 0.41 & & \\
\hline $\begin{array}{l}\text { Unemployment-to- } \\
\text { Nonparticipation Probability }\end{array}$ & & & 0.13 & 0.33 & & \\
\hline $\begin{array}{l}\text { Nonparticipation-to- } \\
\text { Employment Probability }\end{array}$ & & & & & 0.08 & 0.26 \\
\hline $\begin{array}{l}\text { Nonparticipation-to- } \\
\text { Unemployment Probability }\end{array}$ & & & & & 0.07 & 0.26 \\
\hline \multicolumn{7}{|l|}{ Explanatory Variables } \\
\hline $\begin{array}{l}\text { Black } \\
\text { (1=Black) }\end{array}$ & 0.08 & 0.27 & 0.16 & 0.37 & 0.17 & 0.37 \\
\hline $\begin{array}{l}\text { Hispanic } \\
\text { (1=Hispanic) }\end{array}$ & 0.13 & 0.34 & 0.18 & 0.38 & 0.12 & 0.32 \\
\hline Undiff & 2.55 & 2.28 & 3.38 & 2.21 & 2.88 & 2.20 \\
\hline Age & 40.73 & 8.85 & 39.57 & 9.15 & 42.48 & 9.44 \\
\hline Age Squared & 1737.39 & 715.13 & 1649.73 & 729.20 & 1893.44 & 769.50 \\
\hline $\begin{array}{l}\text { Marital Status } \\
\text { (1=Married) }\end{array}$ & 0.66 & 0.47 & 0.46 & 0.50 & 0.40 & 0.49 \\
\hline $\begin{array}{l}\text { Education } 1 \\
\text { (1=Less than High School) }\end{array}$ & 0.09 & 0.29 & 0.18 & 0.38 & 0.22 & 0.41 \\
\hline $\begin{array}{l}\text { Education } 2 \\
\text { (1=High School) }\end{array}$ & 0.31 & 0.46 & 0.41 & 0.49 & 0.40 & 0.49 \\
\hline $\begin{array}{l}\text { Education } 3 \\
\text { (1=Some College No Degree) }\end{array}$ & 0.22 & 0.42 & 0.22 & 0.42 & 0.21 & 0.41 \\
\hline $\begin{array}{l}\text { Education } 4 \\
\text { (1=College and Above) }\end{array}$ & 0.38 & 0.49 & 0.19 & 0.39 & 0.17 & 0.38 \\
\hline $\begin{array}{l}\text { Type of Worker } 1 \\
\text { (1=Government) }\end{array}$ & 0.13 & 0.34 & 0.05 & 0.22 & & \\
\hline $\begin{array}{l}\text { Type of Worker } 2 \\
\text { (1=Private) }\end{array}$ & 0.74 & 0.44 & 0.88 & 0.32 & & \\
\hline $\begin{array}{l}\text { Type of Worker } 3 \\
\text { (1=Self-employed) }\end{array}$ & 0.13 & 0.34 & 0.07 & 0.25 & & \\
\hline $\begin{array}{l}\text { Industry } 1 \\
\text { (1=Agriculture) }\end{array}$ & 0.02 & 0.15 & 0.02 & 0.15 & & \\
\hline $\begin{array}{l}\text { Industry } 2 \\
\text { (1=Mining) }\end{array}$ & 0.01 & 0.12 & 0.01 & 0.11 & & \\
\hline $\begin{array}{l}\text { Industry } 3 \\
\text { (1=Construction) }\end{array}$ & 0.13 & 0.34 & 0.27 & 0.45 & & \\
\hline $\begin{array}{l}\text { Industry } 4 \\
\text { (1=Manufacturing) }\end{array}$ & 0.15 & 0.36 & 0.15 & 0.36 & & \\
\hline
\end{tabular}




\begin{tabular}{|c|c|c|c|}
\hline $\begin{array}{l}\text { Industry } \mathbf{5} \\
\text { (1=Wholesale \& Retail) }\end{array}$ & 0.13 & 0.34 & 0.12 \\
\hline $\begin{array}{l}\text { Industry } 6 \\
\text { (1=Transportation \& Utilities) }\end{array}$ & 0.08 & 0.27 & 0.06 \\
\hline $\begin{array}{l}\text { Industry } 7 \\
\text { (1=Information) }\end{array}$ & 0.03 & 0.16 & 0.02 \\
\hline $\begin{array}{l}\text { Industry } 8 \\
\text { (1=Financial Activities) }\end{array}$ & 0.06 & 0.24 & 0.04 \\
\hline $\begin{array}{l}\text { Industry } 9 \\
\begin{array}{l}\text { (1=Professional } \quad \text { and } \quad \text { Business } \\
\text { Services) }\end{array}\end{array}$ & 0.12 & 0.32 & 0.12 \\
\hline $\begin{array}{l}\text { Industry 10 } \\
\text { (1=Educational and } \quad \text { Health } \\
\text { Services) }\end{array}$ & 0.10 & 0.30 & 0.05 \\
\hline $\begin{array}{l}\text { Industry } \mathbf{1 1} \\
\text { (1=Leisure and Hospitality) }\end{array}$ & 0.06 & 0.24 & 0.08 \\
\hline $\begin{array}{l}\text { Industry } 12 \\
\text { (1=Other Services) }\end{array}$ & 0.04 & 0.20 & 0.04 \\
\hline $\begin{array}{l}\text { Industry } 13 \\
\text { (1=Public Administration) }\end{array}$ & 0.06 & 0.23 & 0.02 \\
\hline
\end{tabular}

Notes: The industry and occupation variables are not present in the samples which contain the Nonparticipation-to-Employment and the Nonparticipation-to-Unemployment transitions because these groups contain individuals whose labor force states start as not in the labor force. The industry and occupation code are only observed for people who are in the labor force, i.e. samples that contain the Employment-to-Unemployment, the Employment-to-Nonparticipation, the Unemployment-toEmployment, and the Unemployment-to-Nonparticipation transitions.

†Undiff $=$ the state-level unemployment rate - the national natural rate of unemployment. 